\title{
Value versus Growth International Real Estate Investment Strategy
}

By

\author{
Kwame Addae-Dapaah* \\ James R. Webb** \\ Ho, Kim Hin/David* \\ Liow Kim Hiang*
}

* Department of Real Estate, National University of Singapore.

** Department of Finance, College of Business, Cleveland State University, Cleveland, Ohio.

Correspondence to:

\author{
Kwame Addae-Dapaah \\ Department of Real Estate \\ School of Design \& Environment \\ National University of Singapore \\ 4 Architecture Drive \\ Singapore 117566
}

Telephone: ++ 6565163417 Fax: ++ 6567748684

E-mail: rstka@nus.edu.sg 


\title{
Value versus Growth International Real Estate Investment
}

\begin{abstract}
We use office and retail properties return data for US and some Asia Pacific cities to ascertain the relative performance of value and growth investment strategies. The results reveal that value portfolios outperform growth portfolios. Furthermore, while the results show that risk varies over time, time-varying risk analyses generally do not support the risk-based explanation for the value premium. Similarly, conditional market regressions do not explain the value premium anomaly as all the alphas are positive and significant. Moreover, the results imply that na"1ve extrapolation of past performance could be a credible explanation for the value premium.
\end{abstract}

KEYWORDS: Value investment strategy, value properties, growth properties, beta premium, beta premium sensitivity, value premium.

\section{Introduction}

The choice of an investment strategy is an important step in the decision-making process of fund managers and large institutional investors. In view of this, growth stock investment strategy and value stock investment strategy have received considerable attention in the finance literature. The growth stock investment strategy is frequently associated with investments in glamour stocks that have relatively high price-to-earnings ratios (i.e. high gross income multiplier in real estate terms). On the other hand, value stock investment strategy usually involves investing in stocks that have recently experienced low or negative growth rates in corporate earnings. Thus, they characteristically have relatively low market price in relation to earnings per share (EPS), cash flow per share, book value per share, or dividend per share (i.e. low gross income multiplier). Notwithstanding their past abysmal performance, studies show that investments in value stocks outperform growth stocks in major markets (see for example, Fama and French 1993, 1995, 1996, 
1998], Capual et al. 1993; Lakonishok et al. 1994; Haugen 1995; Arshanapali et al. 1998; Levis and Liodakis 2001; Badrinath and Omesh 2001; and Chan and Lakonishok 2004).

Although studies such as Jones (1993) and Kryzanowski and Zhang (1992) do not support the relative superiority of value investments, the finance academic fraternity virtually agrees that value investment strategies generally outperform growth investment strategies.

The main debate about value investment strategy centers on the rationale for the value superiority. Several explanations including the risk-based theory and the behavioral finance paradigm have been given for the value premium (i.e. positive value-minus-growth) anomaly. The risk-based school of thought (e.g. Fama and French 1993, 1995, 1996; Campbell and Vuolteenaho, 2004; Li et al., 2009; Cohen et al., 2009 and Campbell et al., 2010) argues that the value premium is a function of risk. According to Petkova and Zhang (2005), value/growth betas covary positively/negatively with the expected market risk premium. Thus, value-minus-growth betas tend to covary positively with the expected market risk premium. Acceptance of the riskbased hypothesis implies that the value strategy has nothing spectacular to offer investors while a rejection of it implies that investors stand to gain by adopting the value strategy.

Moreover, the behavioral finance group argues that value strategies are not fundamentally riskier than growth strategies. Value strategies rather exploit the suboptimal behavior of the typical investor to provide higher returns than growth strategies (see for example, Lo and MacKinlay, 1990; Lakonishok et al. 1994; La Porta et al. 1997). As stated by Dorsey (2004: v), "the history of markets is the history of human error". While Dorsey's (2004) statement may somewhat be an exaggeration, it should be noted that market price, being a product of the judgments of fallen men, may not always be accurate - Fallibility is embedded in almost every action of mankind. As observed by Clendenin (1955:30): "it is not to be expected that market prices, which reflect the current judgments of fallible men, will at all times show accurate appraisals of investment assets. 
Market prices are often slow and erratic in arriving at logical levels, but they are forever searching for them". Similarly, Friday (1922:203) states that "the market, with its scale of prices, does not always give the information which is needed as a basis for rational economic conduct..." These statements are in harmony with Rubin (2000:56): "But everything I have experienced suggests that, at core, economic conditions and markets are grounded in the human psyche. That is, confidence or the lack thereof, profoundly affects markets and economies, and confidence in turn, has throughout history of markets and economies tended to swing from excesses in one direction to excesses in the other". Thus, so far as there are investors in the market who exhibit suboptimal behavior, and human beings are prone to error, value investment strategists can exploit these market inefficiencies to earn a value premium which may not be a compensation for risk.

The extant literature on the value premium predominantly relates to equities. We apply the value/growth investment strategies to a different asset class, real estate, to explore the provenance of the value premium (if any) in real estate investment. Therefore, the objectives of the study are:

i) to ascertain the comparative advantage(s), in terms of performance, of value real estate investment;

ii) to ascertain whether value real estate investment premium, if any, is a function of risk;

iii) to establish whether excessive extrapolation and expectational errors characterize value and growth property investment strategies.

We find that the value strategies generally outperform the growth strategies. Furthermore, the results do not support the risk-based hypothesis. In other words, the superior performance of the value portfolios is not necessarily a compensation for risk. In contrast, the evidence suggests that naïve extrapolation of past performance and expectational errors are a credible explanation for the value premium. 
There are a few reasons why the results support the behavioral rather than the risk-based view. The direct property market is known to be imperfect due to, among other things, heterogeneity of the asset, illiquidity, lumpiness, fixity in location, inelastic supply and the presence of relatively uninformed market participants. Kinnard, Jr. (1971:11) states that as a result of the imperfection of the property market, "price and value are not synonymous and are infrequently equal" (see also Bennet, 2000). According to Baum et al. (1996:40) “...dealers in frequently traded equities are price takers whereas property dealers... are price makers, albeit they may make the wrong price". Moreover, the impossibility of short selling and illiquidity of real estate make arbitraging in the direct property market prohibitively expensive if not impossible (see Phalippou, 2007; Shleifer, 2000; Shleifer and Vishny, 1997; De Long et al., 1990; Wurgler and Zhuravskaya, 2000). The end result of all these is the high probability of mispricing especially in view of the presence of individual investors who are relatively uninformed (see Phalippou, 2007; Baum et al., 1996). In addition, one of the bases for the risk-based explanation, Cash Flows (Campbell, 1993, 1996; Campbell and Vuolteenaho, 2004) may not be as problematic for real property as they are for equities - real property cash flows, as proxied by rent which is contractual, are relatively certain over a lease period to negate the risk-based explanation premised on cash flows.

The rest of the paper proceeds as follows. The next section provides a brief review of the finance literature on the value investment strategy after which, a set of research hypotheses are formulated. This is followed by a discussion on data sourcing and management, and the value strategy model. The next section is devoted to the empirical model estimation which is followed by a post-model estimation. The last section deals with concluding remarks.

\section{Literature Review}

According to Dreman (1982) a contrarian investor is an investor who goes against the "grain". Thus, contrarian investment strategy simply refers to investment in securities which have lost favor with investors. It covers various investment strategies based on buying/selling stocks that 
are priced low/high relative to accounting measures of performance - earnings-to-price ratios $(\mathrm{E} / \mathrm{P})$, cash flow-to-price ratio $(\mathrm{C} / \mathrm{P})$ and book value-to-price ratio $(\mathrm{B} / \mathrm{P})$ - as well as strategies based on low/high measures of earning per share (EPS) growth (Capual 1993). In simple terms, the contrarian investment strategy refers to the value/growth stock paradigm.

While there is substantial empirical evidence supporting the efficient market hypothesis (EMH) that security prices provide unbiased estimates of the underlying values, many researchers question the validity of EMH. Smidt (1968) argues that one potential source of market inefficiency is inappropriate market response to information. The inappropriate response to information implicit in Price-Earnings (P/E) ratios may be an indicator of future investment performance of a security. Proponents of this price-ratio hypothesis claim that low P/E securities tend to outperform high P/E stocks (Williamson, 1970). Basu (1977), Jaffe et al. (1989), Fama and French (1992, 1998), Davis (1994), Lakonishok et al. (1994), Bauman et al. (1998), Badrinath and Omesh (2001) and Chan and Lakonishok (2004) show a positive relationship between earnings yield and equity returns. However, as a result of the noisy nature of earnings (i.e. the category of stocks with low E/P include also stocks that temporarily have depressed earnings), value strategies based on $\mathrm{E} / \mathrm{P}$ give narrower spreads than other simple value strategies (Chan and Lakonishok 2004). Furthermore, in view of the noise in reported earnings that result from Japanese accounting standards (i.e. distortions in the earnings induced by accelerated depreciation allowances), Chan et al. (1991) do not find evidence of a strong positive earnings yield effect after controlling for the other fundamental variables.

Rosenberg et al. (1985) show that stocks with high Book Value relative to Market Value of equity (BV/MV) outperform the market. Further studies, e.g. Chan et al. (1991) and Fama and French (1992), confirm and extend these results. In view of the highly influential paper by Fama and French (1992), academics (e.g. Capaul et al. 1993; Davis 1994; Lakonishok et al. 1994; La Porta et al. 1997; Fama and French 1998; Bauman et al. 1998 and 2001; Chan et al. 2000; and 
Chan and Lakonishok 2004) have shifted their attention to the ratio of BV/MV as one of the leading explanatory variables for the cross-section of average stock returns.

Although BV/MV has gained much credence as an indicator of value-growth orientation, it is by no means an ideal measure (Chan and Lakonishok 2004). BV/MV is not a 'clean' variable uniquely associated with economically interpretable characteristics of the firm (Lakonishok et al. 1994) as many different factors are reflected in this ratio. For example, low BV/MV may describe a company with several intangible assets that are not reflected in accounting book value. A low BV/MV can also describe a company with attractive growth opportunities that do not enter the computation of book value but do enter the market price. A stock whose risk is low and future cash flows are discounted at a low rate would have a low BV/MV as well. Finally, a low BV/MV may be reminiscent of an overvalued glamour stock.

The shortcomings of accounting earnings have motivated a number of researchers to explore the relationship between cash flow yields and stock returns. High Cash Flow to Price (CF/P) stocks are identified as value stocks because their prices are low per dollar of cash flow, or the growth rate of their cash flows is expected to be low. Chan et al. (1991), Davis (1994), Lakonishok et al. (1994), Bauman et al. (1998), Fama and French (1998), and Chan and Lakonishok (2004) show that a high ratio of $\mathrm{CF} / \mathrm{P}$ predicts higher returns. This is consistent with the idea that measuring the market's expectations of future growth more directly gives rise to better value strategies (La Porta 1996).

Fama and French (1998) and Bauman et al. (1998) use the ratio of Dividends to Price (D/P) as a proxy for the market's expectation of future growth. Firms with higher ratios have lower expected growth and are considered to be value stocks. They show that the performance of the value stocks based on dividend yields is quantitatively similar to the performance based on the foregoing categorizations (i.e. P/E, BV/MV and $\mathrm{CF} / \mathrm{P}$ ). Finally, instead of using expectations of future growth to operationalize the notions of glamour and value, Davis (1994) and Lakonishok et al. 
(1994) use past growth to classify stocks. Davis (1994) and Lakonishok et al. (1994) use Growth in Sales (GS) as a proxy for past growth to conclude that the spread in abnormal returns is sizeable.

Since the different valuation indicators of value-growth orientation are not highly correlated, a strategy based on information from several valuation measures may enhance portfolio performance. Lakonishok et al. (1994) explore sophisticated two-dimensional versions of simple value strategies. According to the two-way classification, value stocks are defined as those that have shown poor growth in sales, earnings and cash flow in the past, and are expected by the market to maintain such poor performance in the future. Expected performance is measured by multiples of price to current earnings and cash flow. La Porta et al. (1997) form portfolios on the basis of a two-way classification based on past GS and CF/P introduced by Lakonishok et al. (1994). Using robust regression methods, Chan and Lakonishok (2004) estimate cross-sectional models that predict future yearly returns from beginning-year values of the BV/MV, CF/P, E/P and the sales to price ratios. The use of the multiple measures in the composite indicators enhances the performance of the value strategy (see Gregory et al. 2003).

In contrast to the above findings, Jones (1993) reports that the profitability of value portfolios is a pre-WW II phenomenon that has since largely disappeared. However, this has been refuted by later studies which include post-war data. Also, Kryzanowski and Zhang (1992) suggest that positive profits resulting from the use of the value investment strategy are limited to the U.S. stock market. When applied to the Canadian stock market, the DeBondt and Thaler (1985) model does not produce favorable results. Instead of finding significant price reversals, Kryzanowski and Zhang (1992) find that the Canadian stock market exhibits significant price continuation behavior, which does not support the value investment strategy. This is also refuted by later studies that conclude mean-reversion tendency (see for example, Bauman and Miller 1997). 
In view of the accumulated weight of the evidence from past studies, the finance academic fraternity agrees that value investment strategies generally outperform growth investment strategies. The only polemical issue about the value investment strategy is the rationale for its superior performance.

\section{Rationale for Superior Performance of Value Strategies}

Competing explanations for the superior performance of the value strategy include risk premiums (Fama and French 1993, 1995, 1996), systematic errors in investors' expectations and analysts' forecasts - i.e. naïve investor expectations of future growth and research design induced bias (see for example, La Porta et al. 1997; Bauman \& Miller 1997; La Porta 1996; Dechow \& Sloan 1997; Lakonishok et al. 1994; Lo and MacKinlay 1990; Kothari et al. 1995) and the existence of market frictions (Amihud and Mendelson 1986). The traditional school of thought, led by Fama and French $(1993,1995,1996)$, argues that the superior performance is a function of value investment being relatively risky. This school of thought contends that the expected risk premium for the value strategy is higher/lower during bad/good economic times as value-firms are more susceptible to financial distress. Thus, value premium is attributed to time-varying risk (see Chan 1988; Ball and Kothari 1989; Kothari and Shanken 1992; Lettau and Wachter, 2007). Petkova and Zhang (2005) argue that previous studies that contradict the risk-based hypothesis use realized market return (a noisy measure of economic conditions) to measure aggregate economic conditions (see Fama, 1981; and Stock and Watson, 1999). Using more precise measures of aggregate economic conditions (i.e. default spread, the term spread and the short term interest rate), Petkova and Zhang (2005) find that the conditional betas for value stocks covary positively with the expected market risk premium, while growth stocks' conditional betas covary negatively. Furthermore, Petkova and Zhang (2005) find that positive beta-premium sensitivity of value firms is more significant during periods of depression (see also Lettau and Wachter, 2007; Gomes et al., 2003; Dechow et al., 2004). These findings concur with Guo et al. (2005) that value stocks carry higher time-varying risk. Moreover, Petkova and Zhang (2005) 
state that the positive correlation between ex post and ex ante market returns could have led to the classification of good states ex post as bad states ex ante and vice versa to underpin the contrary findings of studies that cast doubt on the risk-based hypothesis.

Lettau and Ludvigson (2001) and Zhang (2005) argue that value is riskier than growth particularly in bad times when the price of risk is high (also see Cornell, 199). Similarly Black and Fraser (2004) find a negative correlation between the value premium and real GDP in the US to conclude that the value premium is a reward for risk during financial distress. It must be noted, however, that the width of the value spread may not be necessarily indicative of risk - it is simply value minus growth. In addition, negative correlation with GDP and positive beta-premium sensitivity of value firms may be attributable to the asymmetric effect of positive and negative earnings surprises on value and growth stocks (Bauman and Miller, 1997; Dreman and Berry, 1995; and Levis and Liodakis, 2001). Negative surprises have been found to have a relatively benign effect on value stocks. This implies that while growth stocks may perform far better than value stocks in good times to narrow the value spread, they perform considerably worse than value stocks in bad times to increase the value spread as value stocks are relatively more resistant to bad news than growth stocks. Thus, negative correlation to GDP and positive value betapremium sensitivity may not be conclusively probative of the value premium being a compensation for time varying risk.

In contrast to Brenan et al. $(2001,2004)$ who document that value stocks have higher Sharpe Ratios and lower cash flow betas than their growth counterparts, Campbell and Vuolteenaho (2004) find that value stocks have considerably higher cash flow betas (bad betas) than growth stocks to support the risk-based explanation. This is replicated by Cohen et al (2009). Adrian and Franzoni (2008) use unobservable long-run changes in risk factor loadings via Kalman filter betas to disprove mispricing in favor of the risk-based explanation. Campbell et al. (2010) replicate Campbell and Vuolteenaho's (2004) finding but add a caveat that VAR results are sensitive to the 
particular VAR specification that is used. Campbell et al's. (2010) second alternative VAR specification reveals that growth stocks' cash flows have higher bad betas too. This caveat is a response to Cohen and Zhang (2009) who find that for most forecasting in variable specifications, value stocks do not usually have higher betas. They find the results of VAR models to be sensitive to the state variables used in the analysis. Thus Cohen and Zhang (2009) suggest limitation of using the cash flow and discount rate approach to draw meaningful conclusions as contradictory conclusions can be drawn, depending on whether the residual news represents the cash flow, or discount rate news. This weakens the risk-based explanation. It must be noted also that cash flow for direct property, as proxied by rent, is more certain than stocks' cash flow. Although Plazzi et al. (2008) find that the cross-sectional dispersions of commercial real estate returns are counter-cyclical (see also Ghysels, 2007), such dispersions are not peculiar to real estate - they are true of most stocks and thus, do not detract from the relative certainty of rent compared to stocks' cash flow. Furthermore, Plazzi et al. (2008) and Ghysels et al (2007) deal with commercial real estate as an entity rather than value versus growth commercial real estate. Similarly, Plazzi et al's (2010) findings that commercial real estate's expected returns and expected rent growth rates are time varying and that cap rates forecast the expected returns for some commercial real estate relate to both value and growth commercial real estate - Their paper does not address the real estate value premium anomaly.

Cohen and Zhang's (2009) findings agree with Lakonishok et al. (1994), MacKinley (1995), La Porta et al. (1995, 1997), Daniel and Titman (1996) that risk-based explanations do not provide a credible rationale for the observed return behavior (see Jaffe et al. 1989; Chan et al. 1991; Chopra et al. 1992; Capaul et al. 1993; Dreman and Lufkin 1997; Bauman et al. 1998, 2001; Nam et al. 2001; Gomes et al. 2003 and Chan and Lakonishok 2004; Davis and Martin, 2008). 
In contrast to the risk-based explanation, the behavioral finance paradigm recognizes psychological influences on human decision-making in which experts (including analysts and investors) tend to focus on, and overuse, predictors of limited validity (i.e. earnings trend in the recent past) in making forecasts (see Covel and Shumway, 2005; Slovic, 2001; Qian, 2008). The impact of recent past data on decision making is in accordance with Kahneman and Tversky (1982:416) who state that people appear to make predictions on the basis of a simple matching rule: "The predicted value is selected so that the standing of the case in the distribution of outcomes matches the standing in the distribution of impressions". Moreover, Qian (2009) find that analyst forecasts, though time-varying, exhibit optimism which is not significantly affected by macroeconomic factors - It is rather affected by time-varying investor sentiments measured by 2 Chicago Board Options Exchange (CBOE) put-call ratios, and the cross-sectional skewness in the forecast errors. In view of systematic errors in investors' expectations and analysts' forecasts, it is argued that a significant portion of value stocks' superior performance is attributable to earnings surprises (see De Bondt and Thaler, 1985; Lakonishok et al., 1994; La Porta, 1996; Chan et al., 2000, 2003; Chan and Lakonishok, 2004; Jegadeesh et al., 2004). According to Dreman and Berry (1995) and Levis and Liodakis (2001), positive and negative earnings surprises have asymmetrical effect on the returns of value and growth stocks. Positive earnings surprises have disproportionately large positive impact on value stocks while negative surprises have relatively benign effect on such stocks (see also Bauman and Miller 1997).

Furthermore, analysts and institutional investors may be motivated by self-interest to gravitate towards growth stocks - Analysts recommend successful (growth) stocks to generate trading commissions and more investment banking business (see Kothari, 2001; Michaely and Womack, 1999; Lim, 2001). Moreover, growth stocks are typically in 'promising' industries, and are thus easier to promote in terms of analyst reports and media coverage than value stocks (Bhushan 1989; and Jegadeesh et al. 2004). Another important factor is that most investors have shorter time horizons than are required for value strategies to consistently pay off (De Long et al. 1990; 
Shleifer and Vishny 1990). In addition, institutional investors act in a fiduciary capacity. Pension fund trustees, in particular, are expected to behave as an "ordinary man of prudence". This implies that they must go with the crowd (i.e. opt for glamour stocks). The result of all these considerations is that value stocks/glamour stocks become under-priced/overpriced relative to their fundamentals. Due to the limits of arbitrage, underreaction and overreaction to positive and negative news (Shleifer and Vishny 1997; Phalippou, 2007; Pepelas, 2008), the mispricing patterns can persist over long periods of time. Moreover, MacKinnon and Al Zaman (2009) find that returns to direct real estate are mean reverting while risk decreases with investment horizon. This implies that growth/value portfolios, which have performed well/poorly in the recent past, are likely to perform poorly/well in the future medium and long investment horizons.

In view of the above discourse, it is hypothesized that:

a) value office and retail properties generate higher returns than their growth counterparts;

b) value office and retail property premium is a compensation for risk; and

c) investors naively extrapolate past performance into future expectations.

These hypotheses will be operationalized through statistical tests.

\section{Data Sourcing and Management}

The paper uses the Jones Lang Lasalle Real Estate Intelligence Service-Asia (JLL REIS-Asia), the Property Council of New Zealand, the Property Council of Australia and NCREIF property databases to classify 73 office property sub-markets and 48 retail property sub-markets into value/growth sub-markets on the basis of yield (Details are obtainable from authors), i.e. E/P ratio which is widely used in the finance literature for such classification.

JLL REIS-Asia dataset consists of ex post quarterly (since 1994) and ex-ante annual (forecasts for the next 4 years) capital and rental values of prime commercial properties for 16 Asia real estate 
market sectors (i.e. eight retail sectors and eight office sectors). The capital and rental values of commercial real estate assets (office and retail) in the eight cities are based on a basket of 30 prime commercial buildings per sector in each city. Rental values are based on actual rents while the capital values are based on transactions and valuation estimates.

The JLL REIS-Asia ex ante data are derived from JLL's proprietary quantitative forecasting and the consensus views of the JLL network of branch offices in Asian cities, namely: Singapore (the Raffles Place CBD), Beijing, Shanghai, Hong Kong (the Central \& major business districts), Bangkok, Manila (Makati CBD), Kuala Lumpur and Jakarta. The criteria for selecting investment grade offices for the dataset are the same for all the markets in the sample. Thus, the dataset provides a basis for comparing like with like. Similarly, the data from the Property Council of New Zealand and the Property Council of Australia are based on market rentals and valuations. The quality of these data is attested by the fact that they have been subsumed by the IPD. All the datasets are extensively used by researchers. The only caveat about the use of different datasets is that one cannot guarantee that the quality is the same across all the datasets. However, the datasets are of very good quality to provide credible results.

The other classification methods discussed in the literature review are not used to classify the data into value/growth properties because of the dearth of information on these accounting measures of classification. This is not a serious handicap as the finance literature shows that the results of studies based on these classification methods confirm, rather than contradict, the research results based on the E/P classification. The data for the office property market are from 1985Q1 to 2005Q3 while the retail property market data are from 1992Q1 to 2005Q3. The study period is constrained by access to data.

The initial yields are measured in U.S. dollars. Decile portfolios are formed on the basis of the end-of-previous-quarter's initial yield. The top decile of the sample with the highest initial yield 
is classified as value property $\left(\mathrm{V}_{\mathrm{p}}\right)$ portfolio while the bottom decile with the lowest initial yield is classified as growth property $\left(\mathrm{G}_{\mathrm{p}}\right)$. Each decile is treated as a portfolio composed of equally weighted properties. The portfolios are reformulated only at the end of each holding period. This system of classification is consistent with the finance literature (see for example, Chan et al. 1991; and Bauman et al., 1998, 2001).

The classification of the property sub-markets into $V_{p}$ and $G_{p}$ portfolios is followed by an examination of the relative performance of the portfolios. Time-varying risk and conditional market regression analyses are then conducted to ascertain the plausibility of the risk-based explanation for the value premium. This is followed by the naïve extrapolation test in an attempt to find an alternative explanation for the value premium.

\section{The Value Strategy Model}

The performance of both the value and growth properties for the office sector are compared on a 5-year, 10-year, 15-year and entire holding-period (of up to 83 quarters) horizons while those for the retail sector are compared on 5-year, 10-year and entire holding-period (of up to 55 quarters). Medium and long term investment horizons are the focus of analyses as real estate investors usually invest long (Ball, 1998). Periodic (i.e. quarter-by-quarter) return measure is used in the evaluation of the relative superiority of the performance of $V_{p}$ and $G_{p}$ portfolios. The periodic returns are quantified as simple holding period returns. Thus, the simple holding period returns are calculated for each quarter and compounded to obtain the multi-year holding-period (e.g. 5year investment horizon) returns as defined in equation (1).

$r_{t}=\left[\left(1+r_{1}\right)\left(1+r_{2}\right) \ldots\left(1+r_{m}\right)\right]-1($ Levy, 1999),

where 
$r_{1}, r_{2} \ldots r_{m}=$ return for each quarter of the period $m$.

$m \quad=$ number of quarters for the holding period.

Equation (1) is more accurate than simply adding the returns for all quarters of a given period (Sharpe et al. 1998). However, Campbell et al. (1997) argue that this method of approximation may break down if the volatility of returns is critical - Simple compounding returns may exaggerate the performance of asset returns. Hence, Campbell et al. (1997) propose continuous compounding for modeling the behavior of asset returns over time.

$$
r_{t}(k)=\log \left(1+R_{t}\right)+\log \left(1+R_{t-1}\right)+\ldots+\log \left(1+R_{t-k+1}\right) \quad \text { (Campbell et al., 1997) }
$$

where,

$R_{t}, R_{t-1} \ldots R_{t-k+1}$ refer to the quarterly returns for each period.

Therefore, the holding period returns for the paper are log returns (i.e. continuously compounded returns) based on Equation (2). The difference between the average returns for the value and the growth portfolios constitutes each period's value-growth spread. A positive value-growth spread indicates superiority of value investing.

The pooled-variance $t$ test and separate-variance $t$ test are then used to determine whether there is a significant difference between the means of the $V_{p}$ and $G_{p}$ portfolios. If the p-value is smaller than the conventional levels of significance (i.e. 0.05 and 0.10 ), the null hypothesis that the two means are equal will be rejected:

$H_{0}: \mu_{\text {value }}=\mu_{\text {growth }}$

$H_{1}: \mu_{\text {value }} \neq \mu_{\text {growth }}$ 
The next step is to determine whether any difference in returns is a function of variation in risk. Traditional measures of risk such as standard deviation of returns and risk-to-return ratio (i.e. coefficient of variation - CV) are first employed for the analysis. This is followed by timevarying risk analysis.

The Levene's Test is used to test the equality of the variances for the value and growth properties:

$$
\begin{aligned}
& H_{0}: \sigma_{\text {value }}^{2}=\sigma_{\text {growth }}^{2} \\
& H_{1}: \sigma_{\text {value }}^{2} \neq \sigma_{\text {growth }}^{2}
\end{aligned}
$$

\section{Expected Market Risk Premium Model}

This section is motivated by Petkova and Zhang (2005) who use two methods to study the timevarying risk of value and growth portfolios: a simple sorting procedure and a more formal testing procedure based on conditional CAPM. The simple sorting procedure uses the correlation of conditional portfolio betas with the expected market risk premium to verify the time-varying risk explanation for the value premium. We therefore calculate the correlation between the market excess returns and conditional betas for the office and retail value and growth portfolios. In addition, we estimate the expected market risk premium via a least square regression of market returns and the observed value-growth spreads for different holding periods as follows:

$$
R M_{t+1}=\alpha_{i}+\gamma_{i t}\left(V G S_{t}\right)+\omega_{i t}
$$

where,

$R M_{t+1} \quad$ refers to the total market return from period $t$ to $t+1$

$\hat{\gamma}_{i t} \quad$ refers to the estimated market risk premium

$V G S_{t} \quad$ refers to the value-growth spread for holding period $t$ 
Hence, $\hat{\gamma}_{i t}$ is an estimate of the risk attached to the value-premium in each time period. This market risk premium forms the basis for classifying the sample periods into four economic states.

The rationale for this classification is that periods with relatively high market risk premium $\left(\hat{\gamma}_{i t}\right)$ should be considered as a more volatile economic state. Therefore, the periods with the highest quartile of the market risk premium are classified as the worst state (trough), the second highest quartile is classified as the next worst (recession), the third highest quartile as the next best (expansion) and the lowest quartile as the best state (peak). The market on which the above classification is based is proxied by Datastream Indices (a composite of REITs and publicly traded real estate stocks) for the Pacific Basin Real Estate Stock Market from 1985Q1 to 2005Q3. The choice of any real estate stock market for this analysis is controversial as there is no single market that perfectly mirrors the Asian, Australian, New Zealand and US markets. However, given that the study focuses on US and Asia Pacific, the chosen market appears to be the best available proxy which may be an "inevitable" limitation of the study.

We then calculate the two conditional betas: the rolling and the fitted betas of the value-growth portfolios for the full sample as well as for each of the economic states. This is repeated for the respective holding periods for both office and retail portfolios.

The rolling beta is calculated via least square regressions of the value-growth premia on the market excess returns using a 20 and 40-period (quarters) moving-average rolling window for both office and retail portfolios, and a 60-period moving-average rolling window for the office portfolio (Eq. 4). The US Treasury Bill rates are used to calculate the market excess returns as the returns are denominated in the US dollar.

$m V G_{t}=\alpha_{i i}+b_{1}\left(m R M_{t+1}-m T B_{t}\right)+\omega_{i i t}$

where, 
$m V G_{t} \quad$ refers to the moving average value-growth spread

$m R M_{t+1} \quad$ refers to the moving average market return from period $t$ to $t+1$

$m T B_{t} \quad$ refers to the moving average 1-year US government bond rate

$b_{1} \quad$ refers to the estimated rolling-beta

The fitted-beta is calculated via least square regressions of the market excess returns on various economic and real estate conditioning variables such as rental yields, the value-growth spread, the term-spread between US government 10-year bond yield and the 1-year US government bond rate and the US Treasury Bill rate. The rolling windows used for calculating the fitted-beta are the same as those for the rolling beta.

$m R M E_{t}=\alpha_{i i i}+b_{i 1} m R R_{t}+b_{i 2} m V G_{t}+b_{i 3} m T M_{t}+b_{i 4} m T B_{t}+\omega_{i i i t}$

and

$\beta_{i t}=b_{i 0}+b_{i 1} m R R_{t}+b_{i 2} m V G_{t}+b_{i 3} m T M_{t}+b_{i 4} m T B_{t}$

where,

$m R M E_{t} \quad$ refers to the moving average market excess returns

$m R R_{t} \quad$ refers to the moving average mean rental yields

$m V G_{t} \quad$ refers to the moving average value-growth spread

$m T M_{t} \quad$ refers to the moving average term-spread

$m T B_{t} \quad$ refers to the moving average US Treasury Bill rate

$\beta_{i t}$ in Eq. 6 is the fitted beta.

The rolling and fitted betas for the value-growth portfolios are calculated for the different economic states to observe any variation across good and bad times. Higher conditional betas during bad economic times relative to good economic times imply that the portfolio betas covary 
positively with market risk. This would provide evidence that time-varying risk could be the explanation for the value-premium.

The above analyses are supplemented with further examination of the beta-premium sensitivity via the generalized method of moments (GMM). If the value strategy exposes investors to greater downside risk, the value beta-premium sensitivity will be positive (see Petkova and Zhang, 2005). This is tested by regressing the conditional betas of value portfolios on the expected market risk premium to estimate $\varphi$ in Eq. (7). The economic and real estate variables [ $R R_{t}, V G_{t}, T M_{t}, T B_{t}$ ] as well as a constant term are the vector of instrumental variables for the estimation equation below.

$m R M E_{t}=\alpha_{i v}+\varphi\left(m R M_{t+1}-m T B_{t}\right)+\omega_{i v t}$

where,

$\varphi$ refers to the beta-premium sensitivity

It follows from the above discourse that if the growth strategy is safer than the value strategy, the growth beta-premium sensitivity will be negative. The one-sided null hypothesis for the value portfolios is $\varphi>0$. It is also tested whether the beta-premium sensitivities for growth portfolios are negative (i.e. $\mathrm{H}_{0}: \varphi<0$ ) and whether value-minus-growth portfolios have positive betapremium sensitivities.

In an environment with time-varying risk, the conditional CAPM (CCAPM) is a natural benchmark for asset pricing. We therefore supplement the above analyses with a more formal test premised on CCAPM. If CCAPM can explain the value premium anomaly, the intercepts of value-growth portfolios must equal zero in conditional market regressions.

\section{Empirical Model Estimation - A Test of the Extrapolation Model}


Following the evaluation of the risk characteristics of the $V_{p}$ and $G_{p}$ portfolios, the next task is to investigate the relationship between the past, the forecasted, and the actual future growth rates. This relationship is largely consistent with the predictions of the extrapolation model that investors are excessively optimistic about growth properties and overly pessimistic about value properties. A direct test of extrapolation (Lakonishok et al. 1994), then, is to compare the actual future rental income and capital growth rates of value and growth properties to their respective past growth rates and expected growth rates as implied by their initial yields. Naïve extrapolation and expectational error exist if actual future growth rates fall short of past growth rates.

\section{Results - Performance of the Value Strategy}

Figures 1a-1d demonstrate the superiority of value strategy over growth strategy. The office value portfolios outperform their growth counterparts in 42 of the 64 and 35 of the 41, five and ten-year holding periods respectively (Figures $1 \mathrm{a} \& 1 \mathrm{~b}$ ). Moreover, the value strategy registers 100\% value premium for the 15 and more than 15 -year holding periods. The mean value/growth office portfolio $\log$ returns for the 5, 10, 15 and more than 15 years holding periods are $60.38 \% / 21.48 \%$, $119.29 \% / 42.85 \%, 225.27 / 66.54 \%$ and $278.78 / 79.62 \%$ respectively (Table 1 - full details are obtainable from authors). Thus, a dollar invested in the value office property portfolio over the entire investment horizon earns, on average, $199.16 \%$ more than a dollar invested in the growth office property portfolio.

\section{Figures 1a-1d}

Similarly, the value retail property portfolio records spectacular performance by registering $100 \%$ value-growth spread for the 10 and more than 10-year holding periods (Figure 2b). Over the 5year investment formation horizons, however, the value retail property portfolio outperforms its glamour counterpart in 29 of the 36 holding periods (Figure 2a). The mean value/growth retail property portfolio $\log$ returns for the 5, 10 and more than 10-year holding periods are 
103.41\%/45.38\%, 197.20\%/79.47\% and 237.62\%/110.90\% respectively (Table 1 - full details are obtainable from authors).

It can be seen from Table 2a that the mean value-growth spread for both office and retail portfolios increases with the length of the holding period. The value-growth spread for the office portfolio increases from approximately 39 basis points for 5-year holding period to 199 basis points for more than 15-year holding period. Similarly the value-growth spread for the retail portfolio increases from 58 basis points for the 5-year holding period to approximately 127 basis points for the more than 10-year holding period. This phenomenon may be attributable to underand over-reaction to earnings news coupled with limits to arbitrage resulting from, among other things, impossibility of short selling in the direct real property market, and heterogeneity, illiquidity and fixed location of real property. Jegadeesh and Titman (1993) observe that underreaction and momentum cause returns to have positive autocorrelation over the three to twelve months subsequent to portfolio formation. Similarly, Daniel et al. (1998) and Barberis et al. (1998) note that underreaction continues to have positive autocorrelation three to twelve months after portfolio formation while overreaction has negative autocorrelation three to five years after portfolio formation. The interaction between the positive and negative autocorrelation over three to twelve months and three to five years respectively could be the reason why the mean value-growth spread is relatively low over the 5-year investment horizon.

Furthermore, long-term reversals (Pepelas, 2008; De Long et al., 1990), i.e. negative autocorrelation over the longer term, cause the value-growth spread to vary positively with the length of the investment horizon (De Bondt and Thaler, 1985). The peculiar characteristics of real property and the market in which it is traded (localized, presence of unsophisticated investors to give rise to noise-trader risk [De Long et al., 1990], etc.), together with property investment often being over the long term, significantly militate against arbitrageurs to prolong the 
overreaction effect(s) over long investment horizons (De Long et al., 1990). Thus, given long-term reversals and the limits to arbitrage (De Long et al., 1990; Pepelas, 2008), any mispricing in the property market resulting from overreaction or anything else could be exploited by value investors to reap substantial profits over long investment horizons.

It is worth noting that the differences between the mean returns for the value and growth portfolios (i.e. the value premia) are statistically significant at both the 0.01 and 0.05 levels (Table 2a). Furthermore, while the differences between the variances for the value and growth portfolios are not statistically significant for 5-year (office and retail) and 10-year holding periods (office only), the differences are statistically significant for the remaining holding periods (Table 2b). This may imply that the value strategy is riskier than the growth strategy over long investment horizons (i.e. at least 10 and 15 years for retail and office respectively). This is confirmed by the coefficient of variation (Table 1) especially for the retail portfolios. The relative riskiness of the value strategy is examined via the beta premium (through the simple sorting procedure) and the beta premium sensitivity (i.e. time-varying risk of value strategies).

Tables $2 \mathrm{a} \& \mathrm{~b}$

Time-Varying Risk of Value Strategies: Beta-Premium

Tables 3 and 4 present the results of time-varying risk analyses of value strategies. The results do not generally support the time-varying risk hypothesis. It is true that the rolling and fitted betas vary across the four states of the economy but the betas do not generally have the expected sign (negative for peak and expansion; positive for trough and recession). The office rolling betas (5year holding period) for "expansion" and "peak" have a positive sign (instead of the expected negative sign), and statistically significant (Table 3a). This implies that the value premium is high at a time when market risk is low. Although the beta for "trough" is positive, that for recession is 
negative but both are statistically insignificant. The corresponding fitted beta for "peak" is both countercyclical and statistically significant to support the time-varying risk hypothesis. However, it must be noted that the corresponding fitted beta for "trough" (though statistically insignificant) carries a negative sign to negate the risk-based explanation for the value premium anomaly. Furthermore, the fitted betas for the "recession" and "expansion" do not carry the correct signs which do not bode well for the time-varying hypothesis.

The results for the 10 and 15-year holding periods for the office sector (Tables $3 \mathrm{~b} \& 3 \mathrm{c}$ ) are virtually similar to those in Table 3a. The office rolling beta for "peak" over the 10-year investment horizon has the correct sign but the remaining rolling betas do not have the correct signs to support the risk-based hypothesis. Apart from the rolling beta for "expansion" (which is statistically significant albeit bearing the wrong sign) the betas are statistically insignificant (Table 3b). The corresponding fitted betas for "recession", "expansion" and "peak" carry the correct signs to support the risk-based hypothesis but the negative sign for the "trough" beta contradicts the hypothesis. Moreover, all the betas are statistically insignificant (Table 3b).

\section{Table $3 b$}

Over the 15-year holding period, the rolling betas for "expansion" and "peak" are countercyclical and statistically significant. This supports the time-varying risk hypothesis. It must be noted, however, that even though the rolling beta for "trough" carries the correct sign, that for "recession" does not - These betas are statistically insignificant. Unfortunately for the timevarying hypothesis, all the office fitted betas for the 15 -year holding period are negative. The negative beta (worrying sign for time-varying hypothesis) for "recession" is statistically significant while that for "expansion" (favoring the hypothesis) is also statistically significant (Table 3b). 
Similarly, the rolling and fitted betas for the retail sector (Tables $4 \mathrm{a} \& \mathrm{~b}$ ), especially for the 10year holding period, do not generally support the time-varying risk hypothesis. For example, the negative retail fitted betas for "trough" and "recession", and the positive beta for "expansion" (all of which are very troublesome for the risk-based hypothesis) are statistically significant. Thus, the analyses of the value premium betas do not provide support for the time-varying risk hypothesis to be a credible explanation for the value premium anomaly. The discussion now turns to the beta-premium sensitivity to see if it will give credence to the risk-based hypothesis.

\section{Table $4 \mathrm{a} \& \mathrm{~b}$}

\section{Beta-Premium Sensitivity}

It is contended that if the value strategy exposes investors to greater downside risk, its betapremium sensitivity will be positive. Alternatively, the-beta premium sensitivity of the growth strategy will be negative. The beta premium sensitivities for both value and growth are reported in Tables 3 and 4. The results for both office and retail sectors are not favorable to the timevarying risk hypothesis. An examination of Tables 3a-c shows that while the rolling beta premium sensitivities are positive for value and growth strategies, the fitted beta premium sensitivities are negative for both value and growth. Most of these sensitivities are not statistically significant.

The results for the retail sector (Tables $4 \mathrm{a} \& \mathrm{~b}$ ) are even worse for the risk-based hypothesis. Once again, the rolling beta premium sensitivities are positive for both value and growth. However, while the value fitted beta premium sensitivities are negative (diametrically opposed to the risk-based hypothesis) for "trough" (both 5 and 10-year holding periods) and "peak" (5-year holding period), the growth fitted beta premium sensitivities are positive (another contradiction to the time-varying risk hypothesis) for "trough" (5 and 10-year holding periods) and "peak" (10year holding period). Moreover, while the rolling beta premium sensitivities for both value and 
growth are statistically significant for the 5- and 10-year holding periods, their fitted counterparts are not statistically significant for the 5-year holding period. The growth fitted beta premium sensitivities for the 10-year holding period are not statistically significant. However, the value fitted beta premium sensitivities for the 10-year holding period (although carrying signs that negate the risk-based explanation) are statistically significant. These results show that risk may not be a credible explanation for the value premium anomaly. We further verify this through conditional market regressions (Ferson and Harvey, 1999). The intercepts for the conditional market regressions should be zero if CCAPM can explain the value premium. The results for the conditional market regressions are reported in Table 5.

All the alphas (i.e. intercepts of the conditional regressions) in Table 5 are significantly greater than zero to imply that CCAPM cannot explain the value premium anomaly. This result is consistent with Petkova and Zhang (2005) and Lewellen and Nagel (2004). Furthermore, the above results concur with studies on stocks (e.g. Lakonishok et al., 1994; Brenan et al., 2004; Davis and Martin, 2008; Cohen and Zhang, 2009, to name a few), which conclude that the value premium is not driven by risk. We therefore explore the extrapolation model to ascertain the possibility of it being a credible provenance of the value premium.

\section{Post-Model Estimation - A Test of the Extrapolation Model}

This section provides empirical evidence to verify whether excessive extrapolation and expectational errors characterize growth and value strategies. First, the study period is divided into two: past (pre-portfolio formation) and future (post-portfolio formation) performances (see Panels B and C respectively of Table 6). Table 6 presents some descriptive characteristics of the growth and value portfolios with respect to their initial yields and past, and future, growth rates. Panel A of Table 6 reveals that the value portfolios have higher initial yields than growth portfolios. This is supposed to portend lower expected growth rates for value properties. Panel B 
shows that the growth portfolio's performance for both sectors (in relation to rental income) and for the retail sector (relative to capital value) is better than the value portfolios during the preportfolio formation period. On the other hand, Panel $\mathrm{C}$ shows that the relative growth of rental income and capital value for growth property portfolios is generally quite below expectation in the subsequent post-portfolio formation years.

\section{Table 6}

Given the Gordon's formula (Gordon and Shapiro, 1956) the differences in expected rental growth rates can be directly calculated from differences in initial yields if discount rates are held constant. Thus, we seek to ascertain whether the large differences in initial yields between value and growth properties can be justified by the differences in future rental growth rates.

Panel B of Table 6 reveals that the average quarterly growth rates for rental income for the glamour portfolio are $14.36 \%$ compared to $0.56 \%$ (office) and $17.40 \%$ compared to minus $1.87 \%$ (retail) for the value portfolio in the pre-portfolio formation period.

Every dollar invested in the value portfolio in 1994Q2 (office) and 1997Q4 (retail) respectively has a claim to 8.57 and 12.22 cents of the corresponding rental income while a dollar invested in the growth portfolio has a claim to 1.69 and 1.75 cents of the rental income (Panel A of Table 6). Ignoring any difference in required rates of return, the large differences in initial yields have to be justified by an expectation of higher rental growth rates for glamour than for value portfolios over a period of time. Thus, the expected rental income for the growth portfolio must be higher than the value portfolio at some future date. Accordingly, investors are keen to know the number of quarters that it takes for the rental income per dollar invested in the growth portfolios $(0.0169$ and $0.0175)$ to equate the rental income of the value portfolios (0.0857, and 0.1222$)$, assuming that the differences in past rental income growth rates persist (i.e. the investments exhibit return 
inertia). It takes approximately 12 quarters (office), and 11 quarters (retail) for such equalization to occur. This is good news for glamour investors as it takes just three years for their portfolios to catch up with, and outperform, value investors if return inertia persists. This fuels high growth expectations which are extrapolated too far into the future by glamour investors.

Unfortunately, a comparison of Panels B and C (Table 6) show that the relatively higher expected future growth (implied by the higher growth rate and lower initial yield in the pre-portfolio formation period) in the glamour portfolios during the post-portfolio formation period is a far cry from reality. The actual post-portfolio formation rental growth rate for glamour portfolios plummets by $58.49 \%$ from $14.36 \%$ to $5.96 \%$ (office) and $79.02 \%$ from $17.4 \%$ to $3.65 \%$ (retail) per quarter. Conversely, the post-portfolio formation rental growth rate for the value portfolios increases by $8.93 \%$ from -0.56 to $-0.51 \%$ (office), and $100.53 \%$ from $-1.87 \%$ to $0.01 \%$ (retail). On the basis of the post-portfolio formation growth rates (Panel $\mathrm{C}$ of Table 6), it takes 28 quarters (7 years) and 56 quarters (14 years) for glamour office and retail portfolios respectively to catch up with their value counterparts. This implies that any underpricing, underreaction/overreaction persists for 7 years (office) and 14 years (retail) before being corrected. This persistence over long periods, coupled with compounding effects, may explain the time-varying nature of the value premium (i.e. why the value premium varies directly with the length of the holding period). These results are consistent with the overreaction/ naïve extrapolation model. Value/glamour investors are pleasantly/unpleasantly surprised by the post-portfolio formation results. Analysis of the capital values of the $V_{p}$ and $G_{p}$ portfolios yields somewhat similar results.

During the pre-portfolio formation period, the capital value growth rate for the glamour retail portfolio $(2.6 \%)$ is higher than the value retail portfolio $(0.21 \%)$. The capital value growth rate for the office glamour portfolio $(-2.14 \%)$, however, is lower than the office value portfolio $(6.99 \%)$ during the pre-portfolio formation period (Table 6, Panel B). The results in Table 6 (Panel C) show that while the capital value growth rate for the retail glamour portfolio declines by $12.69 \%$ 
from $2.6 \%$ to $2.27 \%$, that for the value portfolio increases by $238.1 \%$ from $0.21 \%$ to $0.71 \%$ per quarter in the post-portfolio formation period. Once again, the results are consistent with the extrapolation model.

However, the results for the office portfolio capital value are inconsistent with the extrapolation model. The capital value growth rate for the glamour office portfolio increases by $156.54 \%$ from $-2.14 \%$ to $1.21 \%$ while that of the corresponding value portfolio declines by $134.48 \%$ from $6.99 \%$ to $-2.41 \%$ per quarter. Thus, whereas the value office portfolios' rental value growth rates support the extrapolation explanation for the value premium, its capital value growth rates do not support the extrapolation model. As far as the retail portfolios are concerned, the growth rates (both pre and post portfolio formation) for both rental and capital values support the extrapolation model to imply that extrapolation of past performance into the future is a credible explanation for the value premium.

\section{Conclusion}

The paper set out to investigate the comparative advantage(s) of the value and growth real estate investment strategies to ascertain the credibility of the risk-based explanation for the value premium (if any). The results of the study indicate that value portfolios for the two property sectors (office and retail) generally out-perform growth portfolios over all the holding periods under consideration. A dollar invested in the value portfolios over 10 years, on the average, earns $76.44 \%$ (office) and $117.73 \%$ (retail) more than a dollar invested in the corresponding growth portfolios. Similarly, a dollar invested in the value portfolios over the entire period of study earns, on average, $199.15 \%$ (office) and $126.72 \%$ (retail) more than a similar investment in the growth portfolio. The difference between the performances of the value and the growth portfolios are 
statistically significant at the 0.01 level. Moreover, the value premium increases with the length of the holding period.

Furthermore, the results of the time-varying risk analyses (based on the beta-premium and betapremium sensitivities) generally do not provide support for the risk-based explanation for the value premium anomaly. The results of the beta premium sensitivities analyses, in particular, generally contradict the time-varying risk hypothesis. This is supported by the results of conditional market regressions which show that CCAPM cannot explain the value premium anomaly. Given that the results are consistent with several studies on stocks, we cannot contend that the results are a function of the peculiar nature of real estate and the market in which it is traded. However, it may be noted that the peculiar nature of real estate (illiquidity, lumpiness, etc.) and the real estate market (market imperfection, impossibility of short selling and arbitraging, etc.) could lead to more expectational errors on the part of real estate investors than stock investors. This could be the reason why the results of the naïve extrapolation test generally indicate that overreaction/naïve extrapolation of past performance is a credible explanation for the superior performance of value real estate investment, especially for the retail real estate.

\section{References}

Adrian, T and F. Franzoni. 2008. Learning About Beta: Time-Varying Factor Loadings, Expected Returns, and the Conditional CAPM. http://ssrn.com/abstract=391562.

Arshanapali, B., D. Coggin and J. Doukas. 1998. Multifactor Asset Pricing Analysis of International Value Investment. Journal of Portfolio Management 24(4): 10-23.

Amihud, Y. and H. Mendelson. 1986. Asset Pricing and the Bid-Ask Spread. Journal of Financial Economics. 17: 229-254.

Badrinath S.G. and K. Omesh. 2001. The Robustness of Abnormal Returns From The Earnings Yield Contrarian Investment Strategy. The Journal of Financial Research 24(3): 85-401.

Ball, R. and S. Kothari. 1989. Nonstationary Expected Returns. Journal of Financial Economics 25(1): 51-74.

Barberis, N., A. Shleifer and R. Vishny. 1998. A Model of Investor Sentiment. Journal of Financial Economics 49(3): 307-343. 
Basu, S. 1977. Investment Performance of Common Stocks in Relation to their Price-Earnings Ratio: A Test of the Efficient Market Hypothesis. Journal of Finance 32(3): 6763-6782.

Baum, A., N. Crosby and B. MacGregor. 1996. Price Formation, Mispricing and Investment Analysis in the Property Market. Journal of Property Valuation and Investment 14(1): 36-49.

Bauman, S. and R.E. Miller. 1997. Investor Expectations and the Performance of Value Stocks versus Growth Stocks. Journal of Portfolio Management 23(3): 57-68.

Bauman, W. and C. Conover. 1999. Investor Overreaction in International Stock Markets. Journal of Portfolio Management 25(4): 102-110.

Bauman, W., C. Conover and R. Miller. 2001. The Performance of Growth Stocks and Value Stocks in the Pacific Basin. Review of Pacific Basin Financial Markets and Policies 4(2): 95-108.

Bennet, J. 2000. On Values and Their Estimation. International Journal of Social Economics 27(7/8/9/10): 980-993.

Bhushan, R. 1989. Firm Characteristics and Analyst Following. Journal of Accounting and Economics 11(2/3): 255-274.

Biswas, T. 1997. Decision Making Under Uncertainty. Macmillan Press Ltd.: London.

Black, F. 1993. Beta and return. Journal of Portfolio Management 20(1): 8-18

Brennan, M.J., A. Wang and Y. Xia. 2001. A Simple Model of Intertemporal Capital Asset Pricing and its Implication for the Fama-French Three Factor Model. Unpublished Paper, Anderson Graduate School of Management, UCLA.

Brennan, M.J., A. Wang and Y. Xia. 2004. Estimation and Test of a Simple Model of Intertemporal Capital Asset Pricing. Journal of Finance LIX(4):1743-1775.

Campbell, J.Y.1993. Intertemporal Asset Pricing without Consumption Data. American Economic Review 83:487-512.

Campbell, J.Y.1996 Understanding risk and return. Journal of Political Economy 104(2): 298345.

Campbell, Y.H. and L. Hentschel. 1992. No News is Good News: An Asymmetric Model of Changing Volatility in Stock Returns. Journal of Financial Economics 31(1): 281-318.

Campbell, J.Y., and T. Vuolteenaho. 2004. Bad beta, good beta. American Economic Review 94(5): 1249-1275.

Capaul, C., I. Rowley, and W. Sharpe. 1993. International Value and Growth Stock Returns. Financial Analysts Journal 49(1): 27-36.

Campbell, J.Y., C. Polk and T. Vuolteenaho. 2010. Growth or Glamour? Fundamentals and Systematic Risk in Stock Returns. Review of Financial Studies 23(1):305-344..

Chan, K.C. 1988. On the Contrarian Investment Strategy. Journal of Business 61(2): 147-164 
Chan, L., Y. Hamao and J. Lakonishok. (.1991. Fundamentals and Stock Returns in Japan. Journal of Finance 46(5): 1739-1764.

Chan, L., J. Karceski and J. Lakonishok. 2000. New Paradigm or Same Old Hype in Equity Investing? Financial Analysts Journal 56(4): 23-36.

Chan, L., J. Karceski and J. Lakonishok. 2003. The Level and Persistence of Growth Rates. Journal of Finance 58(2): 643-684.

Chan, L., and J. Lakonishok. 2004. Value and Growth Investing: Review and Update. Financial Analysts Journal 60(1): 71-86.

Chen, L. and X. Zhao. 2009. Return Decomposition. Review of Financial Studies 22(12):52135249 .

Chopra, N., J. Lakonishok and J. Ritter. 1992. Measuring Abnormal Performance: Do stocks overreact? Journal of Financial Economics 31(2): 235-268.

Clendenin, J.C. 1955. Introduction to Investments. McGraw-Hill: New York.

Cohen, R.B., C. Polk and T. Vuolteenaho. 2009. The Price is (Almost) Right. Journal of Finance 64(6):2739-82.

Cornell, B. 1999. The Equity Risk Premium. Chapter 4. Wiley and sons, Inc.

Coval J. D. and T. Shumway. 2005. Do Behavioural Biases Affect Prices? The Journal of Finance 60(1): 1-34.

Daniel, K. and S. Titman.1996. Evidence on the Characteristics of Cross Sectional Variation in Stock Returns. Working Paper. University of Chicago: Chicago, IL.

Davis, J. 1994. The Cross-Section of Realized Returns: The Pre-COMPUSTAT Evidence. Journal of Finance 49(5): 1579-1593.

Davis, M. and R.F. Martin. 2008. Housing, Home Production, and Equity and Value Premium Puzzles. Board of Governors of the Federal Reserve System International Finance Discussion Papers. Unpublished. www.federalreserve.gov/pubs/ifdp/.

De Bondt, W. and R. Thaler. 1985. Does the Stock Market Overreact? Journal of Finance 40(3): 793-805.

Dechow, P. and R. Sloan. 1997. Returns to Contrarian Investment Strategies: Tests of Naïve Expectations Hypothesis. Journal of Financial Economics 43(1): 3-27.

De Long, B., A. Shleifer, L. Summers and R. Waldmann. 1990. Noise Trader Risk in Financial Markets. Journal of Political Economy 98(4): 703-738.

Dreman, D. 1982. The New Contrarian Investment Strategy. Random House: New York. 
Dreman D. and M. Berry. 1995. Overreaction, Underreaction and the Low-P/E Effect. Financial Analysts Journal 51(4): 21-30

Dreman, D.N. and E. A.Lufkin. 1997. Do Contrarian Strategies Work Within Industries? Journal of Investing 6(3): 7-29.

Dorsey, W. 2004. Behavioral Trading: Methods of Measuring Investor Confidence, Expectations, and Market Trends. TEXERE: New York

Fama, E.F. and K.R. French. 1992. The Cross-Section of Expected Stock Returns. Journal of Finance. 47(2): 427-65

Fama E.F. and K.R. French. 1993. Common Risk Factors in the Returns on Stocks and Bonds. Journal of Financial Economics 33(1): 3-56.

Fama E.F. and K.R. French. 1995. Size and Book-to-Market Factors in Earnings and Returns. Journal of Finance 50(1): 131-155.

Fama E.F. and K.R. French. 1996. Multifactor Explanations of Asset Pricing Anomalies. Journal of Finance 51(1): 55-84.

Fama E.F. and K.R. French. 1998. Value versus Growth: The International Evidence. Journal of Finance 53(6): 1975-1999.

Ferson, W. and R.H. Campbell. 1991. The Variationof Economic Risk Premiums. Journal of Political Economy 99: 285-315.

Foster, F.D., T. Smith, and R.E. Whaley. 1997. Assessing Goodness of Fit of Asset Pricing Models: The Distribution of the Maximal R². Journal of Finance 52(2): 591-607.

Friday, D. 1922. An Extension of Value Theory. Quarterly Journal of Economics 36(2): 197-219.

Gentler, D. and N. Miller. 2001. Commercial Real Estate Analysis and Investments. Prentice Hall: New Jersey.

Ghysels, E., A. Plazzi and R. Valkanov. 2007. Valuation in US Commercial Real Estate. European Financial Management 13(3): 472-497.

Gomes, J.F., L. Kogan and L. Zhang. 2003. Equilibrium Cross Section of Returns. Journal of Political Economy 111(4): 693-732.

Gordon, M.J. and E. Shapiro. 1959. Capital Equipment Analysis: the Required Rate of Profit. Management Science 3: 102-110.

Graham, B. and D.L. Dodd. 1934. Security Analysis. McGraw-Hill Book Company, Inc.: New York.

Gregory, A., R.D.F. Harris and M. Michou. 2001. An Analysis of Contrarian Investment strategies in the UK. Journal of Business Finance and Accounting 28(9/10): 1192-1228. 
Haugen, R.A. 1995. The New Finance: The Case Against Efficient Markets. Prentice Hall: New Jersey.

Jaffe, J., D.B. Keim, and R. Westerfield. 1989. Earning Yields, Market Values, and Stock Returns. Journal of Finance 44(1): 135-148.

Jegadeesh, N., J. Kim, S. Krische and C. Lee. 2004. Analyzing the Analysts: When Do Recommendations Add Value? Journal of Finance 59(3): 1083-1124.

Jones, L.S. 1993. Another Look at Time-Varying Risk and Return in a Long-Horizon Contrarian Strategy. Journal of Financial Economics 33(1): 119-144.

Kahneman, D. and A. Tversky. 1982. "Intuitive Prediction: Biases and Corrective Procedures". In D. Kahneman, P. Slovic and A. Tversky (eds.). Judgment Under Uncertainty: Heuristics and Biases. Cambridge University Press: UK

Kinnard, W.N. 1971. Income Property Valuation: Principles and Techniques of Appraising income-producing real estate. Heath Lexington Books: Lexington, Mass.

Kothari, S.P. 2001. Capital Markets Research in Accounting. Journal of Accounting and Economics 31: 105-231.

Kothari, S.P. and J. Shanken. 1992. Stock Return Variation and Expected Dividends: A Time Series and Cross-Sectional Analysis. Journal of Financial Economics 31(2): 177-210.

Kothari, S.P., J. Shanken, and R.G. Sloan. 1995. Another Look at the Cross-Section of Expected Stock Returns. Journal of Finance 50(1): 185-224.

Kryzanowsji, L. and H. Zhang. 1992. The Contrarian Investment Strategy Does Not Work in Canadian Markets. Journal of Financial and Quantitative Analysis 27(3): 383-395.

La Porta, R. 1996. Expectations and the Cross-Section of Stock Returns. Journal of Finance 51(5): 1715-1742.

La Porta, R., J. Lakonishok, A. Shleifer, and R. Vishny. 1997. Good news for Value Stocks: Further Evidence on Market Efficiency. Journal of Finance 52(2): 859-874.

Lakonishok J., A. Shleifer, and R. Vishny. 1994. Contrarian Investment, Extrapolation and Risk. Journal of Finance 49(5): 1541-1578.

Levis, M. and M. Liodakis. 2001. Contrarian Strategies and Investor Expectations. Financial Analysts Journal 57(2): 43-56.

Lettau, M. and J. Wachter. 2007. Why Is Long-Horizon Equity Less Risky? A Duration-Based Explanation of the Value Premium. Journal of Finance, LXII(1), 55 - 88.

Li, X., C. Brooks and J. Miffre. 2009. The Value Premium and Time Varying Volatility. Journal of Business Finance and Accounting 36(9-10):1252-1272.

Lim, T. 2001. Rationality and Analyst Forecast Bias. Journal of Finance 56: 369-385.

Lo, A.W., and A.C. MacKinlay. 1990. Data-Snooping Biases in Tests of Financial Asset Pricing Models. Review of Financial Studies 3(3): 431-468. 
Lo, A.W. and A.C. MacKinlay. 1988. Stock Market Prices Do Not Follow Random Walks: Evidence from a Simple Specification Test. The Review of Financial Studies 1(1): 41-66.

MacKinlay, A.C. 1995. Multifactor models do not explain deviations from the CAPM. Journal of Financial Economics 38(1): 3-28.

MacKinnon, G.H., and Al Zaman, A. 2009. Real Estate for the Long Term: The Effect of Return Predictability on Long-Horizon Allocations. Real Estate Economics 37(1): 117-153.

Michaely, R. and K. Womack. 1999. Conflict of Interest and the Credibility of Underwriter Analyst Recommendations. Review of Financial Studies 12: 653-686.

Nam, K., C.S. Pyun and S.L. Avard. 2001. Asymmetric Reverting Behaviour of Short-horizon Stock Returns: An Evidence of Stock Market Overreaction. Journal of Banking and Finance 25(4): 807-824.

Pepelas, A. 2008. Testing the Overreaction Hypothesis in the UK Stock Market by using Inter \& Intra Industry Contrarian Strategies. http://papers.ssrn.com/sol3/papers.cfm?abstract_id=1282776

Phalippou, L. 2007. Can Risk-Based Theories Explain the Value Premium? Review of Finance 11: $143-166$.

Plazzi, A., W. Torous and R. Valkanov. 2008. The Cross-Sectional Dispersion Of Commercial Real Estate Returns and Rent Growth: Time Variation and Economic Fluctuations. Real Estate Economics 36(3): 403-439.

Plazzi, A., W. Torous and R. Valkanov. 2010. Expected Returns and Expected Growth in Rents of Commercial Real Estate. Review of Financial Studies 23(9): 3469-3519.

Qian, H. 2009. Time Variation in Analyst Optimism: An Investor Sentiment Explanation. Journal of Bahavioral Finance 10: 182-193.

Rosenberg, B., K. Reid and R. Lanstein. 1985. Persuasive Evidence of Market Inefficiency. Journal of Portfolio Management 11(1): 9-17.

Rubin, R. 2000.What Have We Learnt? The World in 2000 (The Economist Publication, January 2000).

Sharpe, W., G. Alexander, G. and J. Bailey. 1998. Investments. $6^{\text {th }}$ Edition. Prentice Hall: New Jersey.

Shleifer, A. 2000. Inefficient Markets. An Introduction to Behavioral Finance. Oxford University Press: Oxford.

Shleifer, A. and R. Vishny. 1990. The New Theory of the Firm: Equilibrium Short Horizons of Investors and Firms. AEA Papers and Proceedings 80(2): 148-153.

Shleifer, A. and R. Vishny. 1997. The Limits of Arbitrage. Journal of Finance 52(1): 35-55.

Slovic, P. 2001. Psychological Study of Human Judgment: Implications for Investment Decision Making. Journal of Psychology and Financial Markets 2(3): 160-172.

Wurgler, J. and E. Zhuravskaya. 2000. Does Arbitrage Flatten Demand Curves for Stocks? Journal of Business 75(4): 583-6 
Figure 1a: Office value Premium (5-Year Holding Period)

The figure displays the time-varying office value premia for the different 5-year investment horizons.

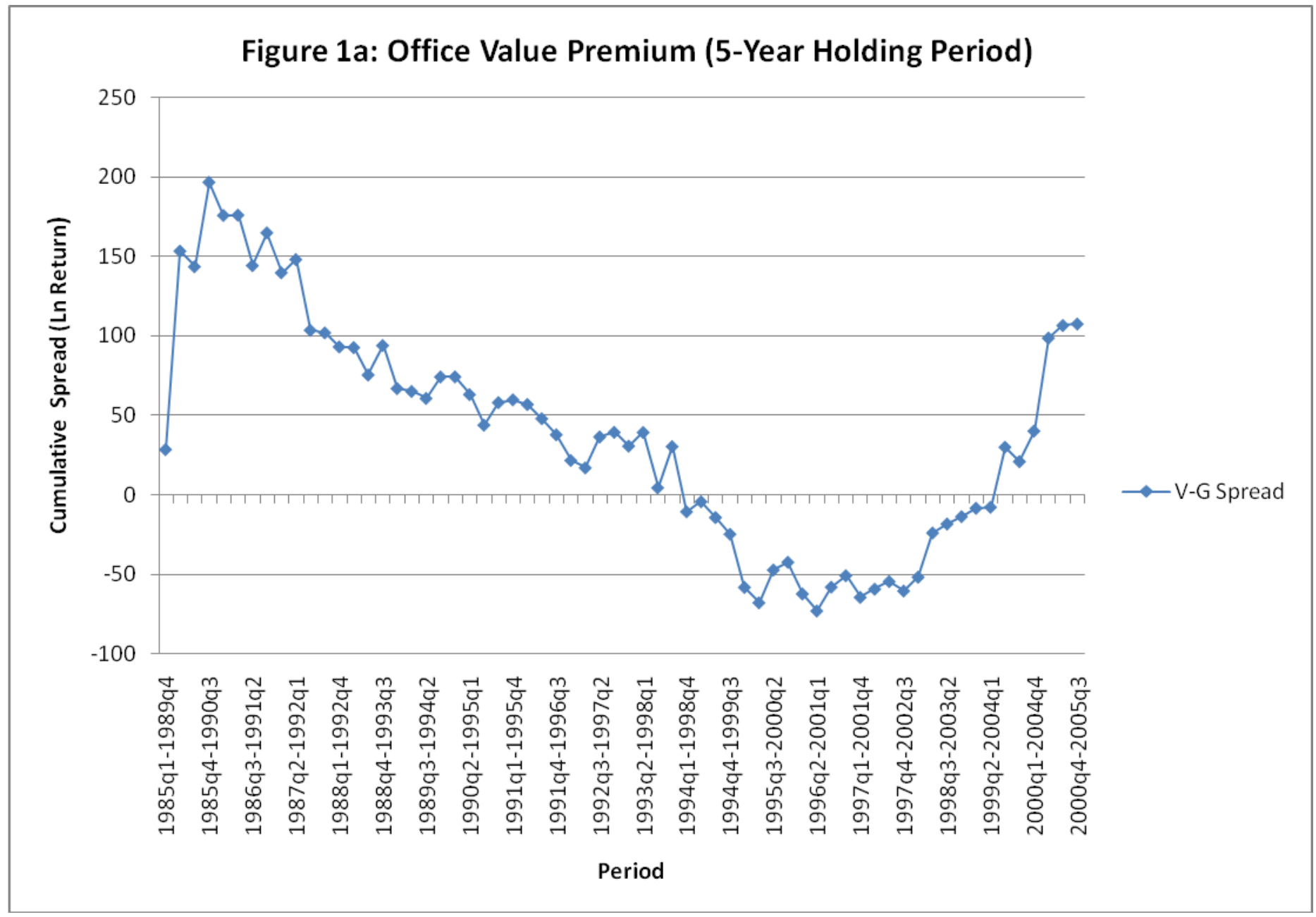


Figure 1b: Office Value Premium (10-Year Holding Period)

The graph depicts the time-varying office value premia for the different 10-year holding periods.

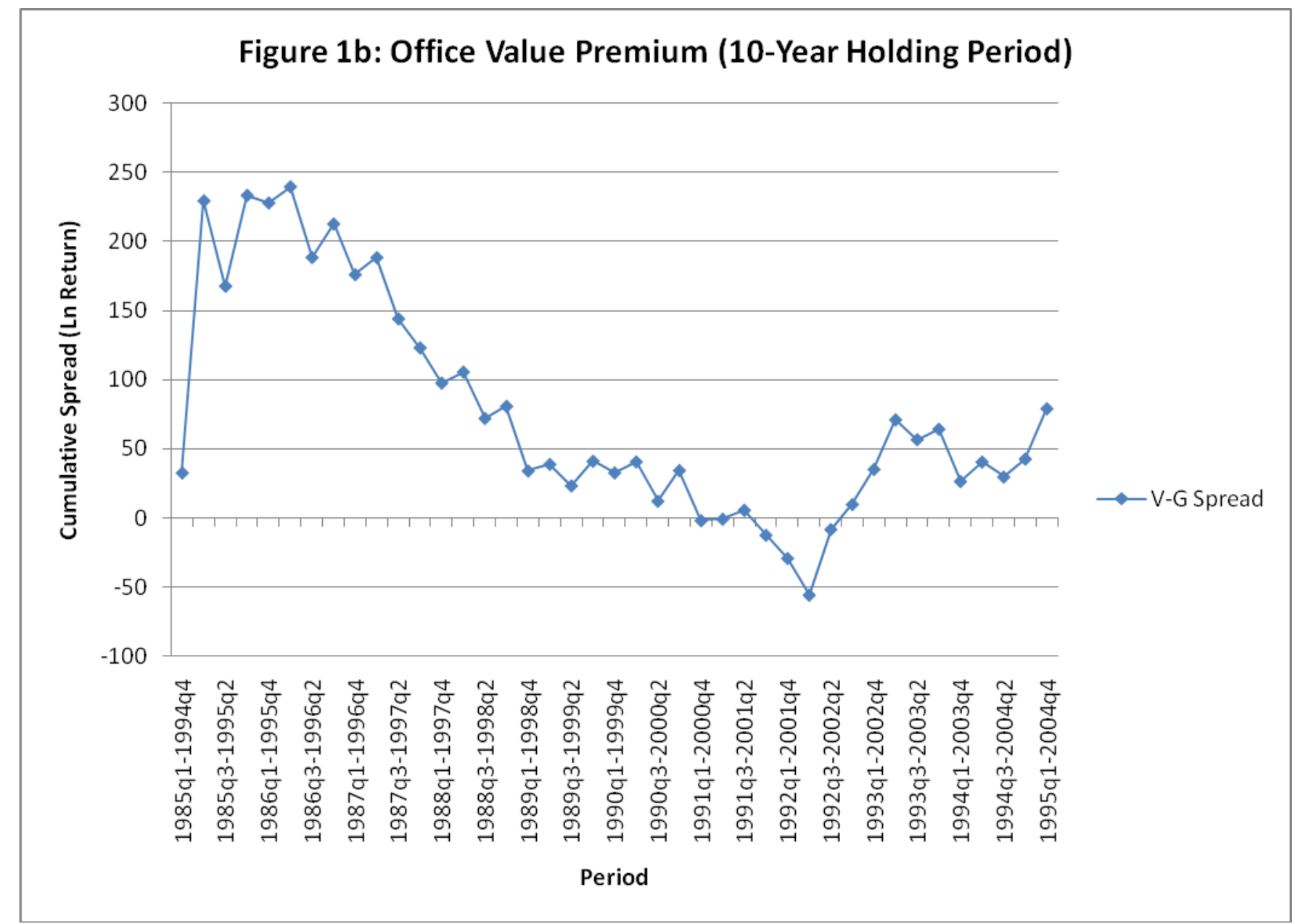


Figure 1c: Office Value Premium (15-Year Holding Period)

The graph depicts the time-varying office value premia for the different 15-year investment horizons.

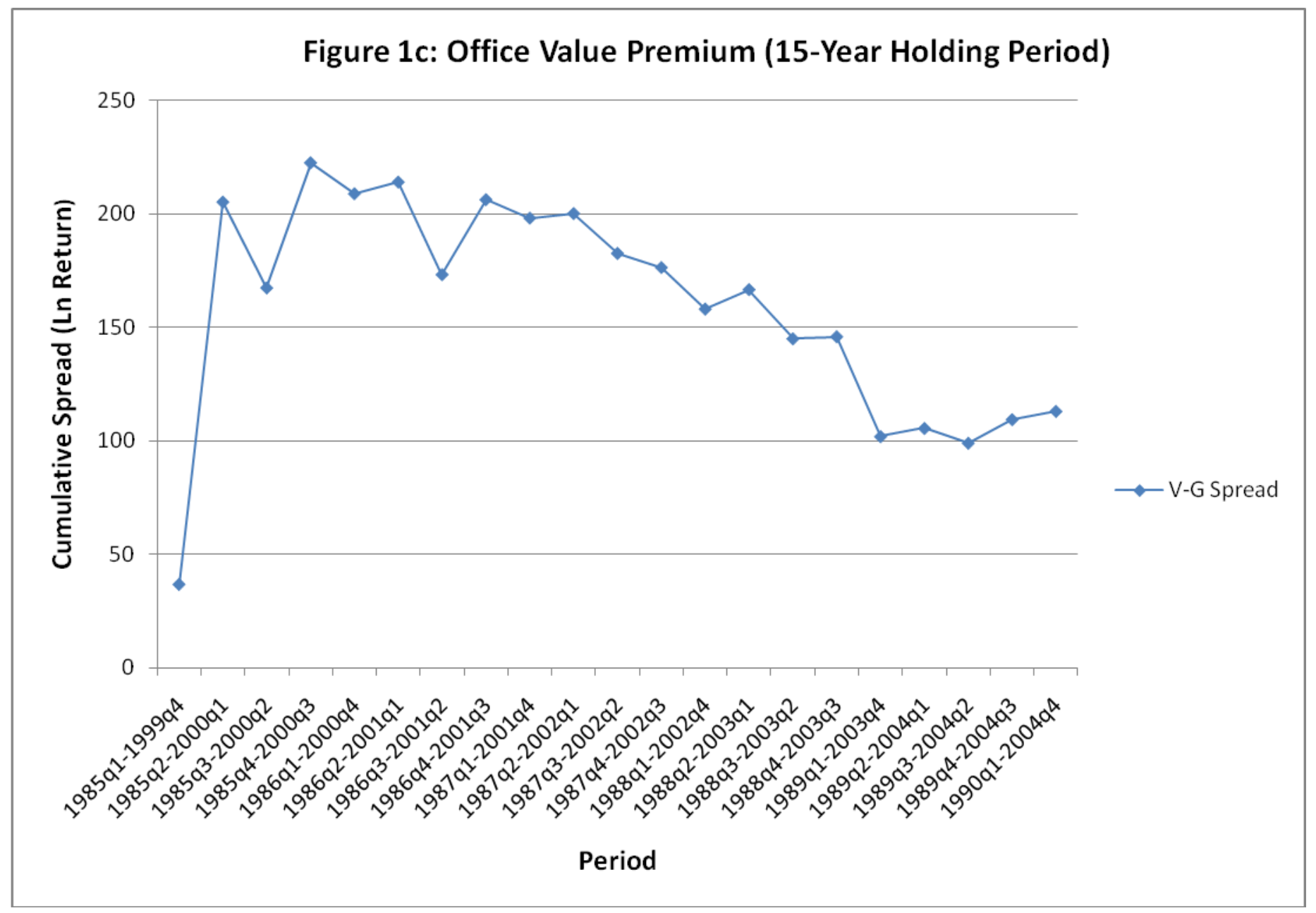


Figure 1d: Office Value Premium (Holding Periods Exceeding 15 Years)

The figure depicts the time-varying office value premia for the different holding periods exceeding 15 years.

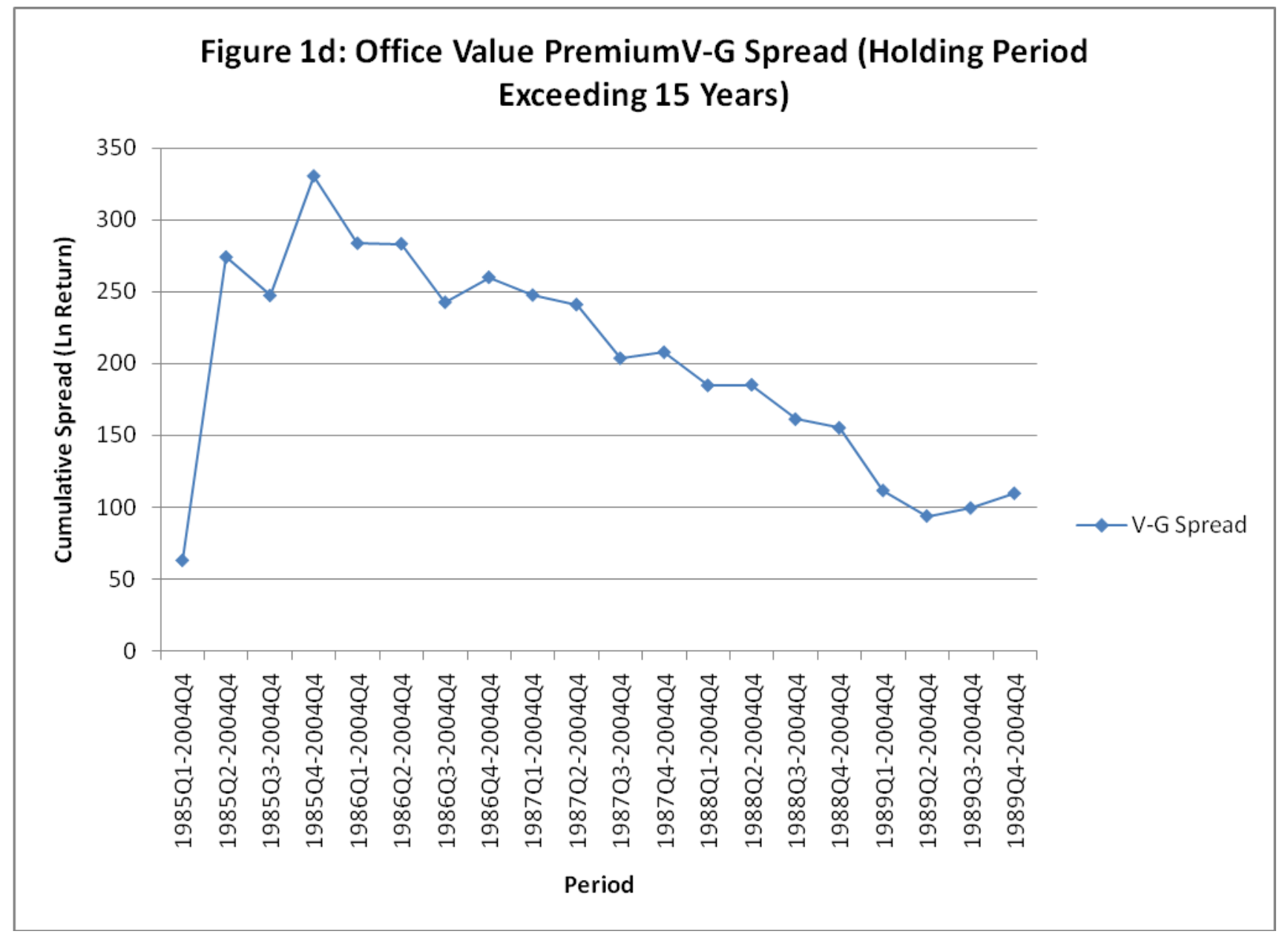


Figure 2a: Retail Value Premium (5-Year Holding Period)

The figure displays the time-varying retail value premia for the different 5-year investment horizons.

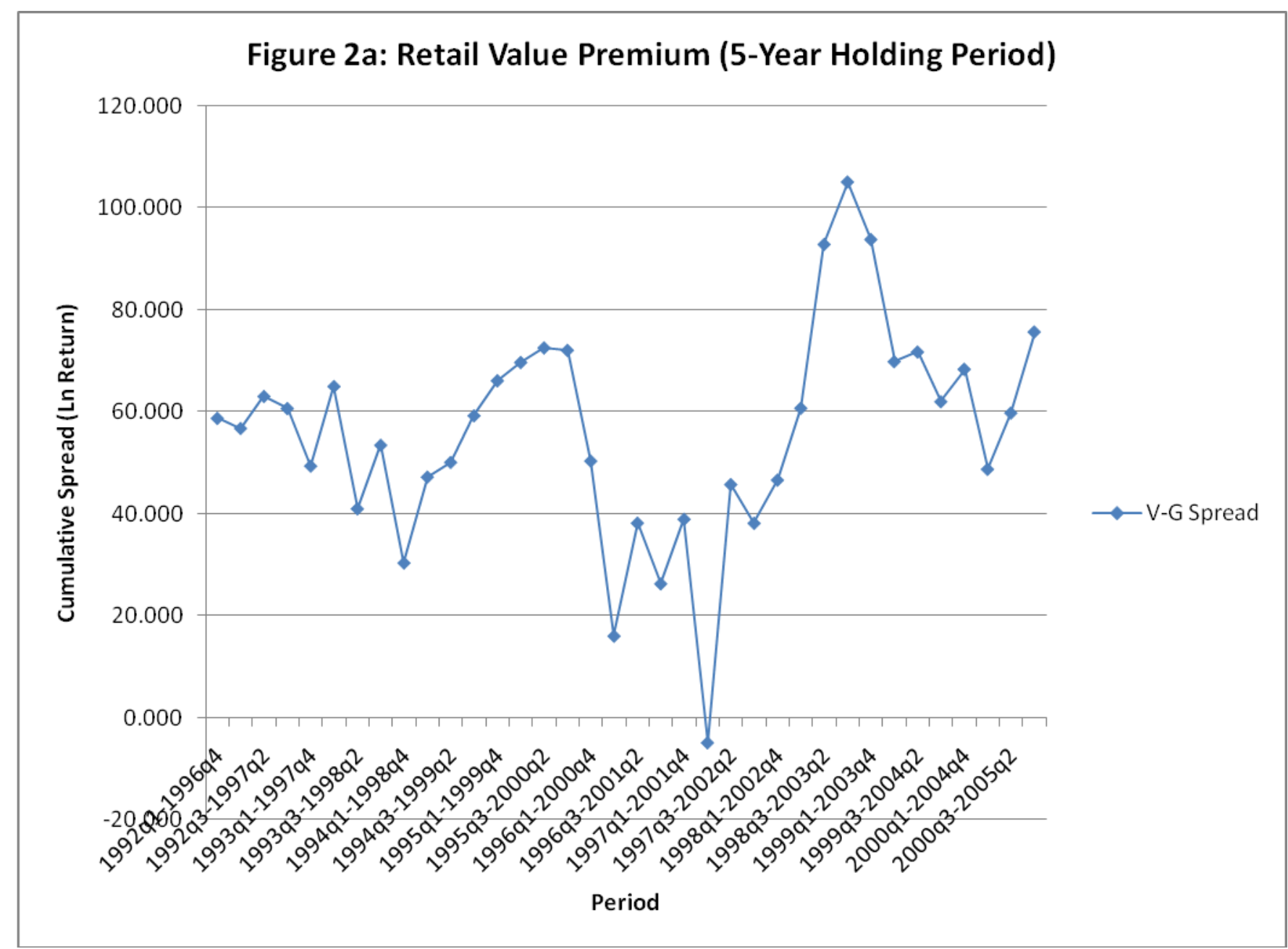


Figure 2b: Retail Value Premium (10-Year Holding Period)

The figure displays the time-varying retail value premia for the different 10 -year investment horizons.

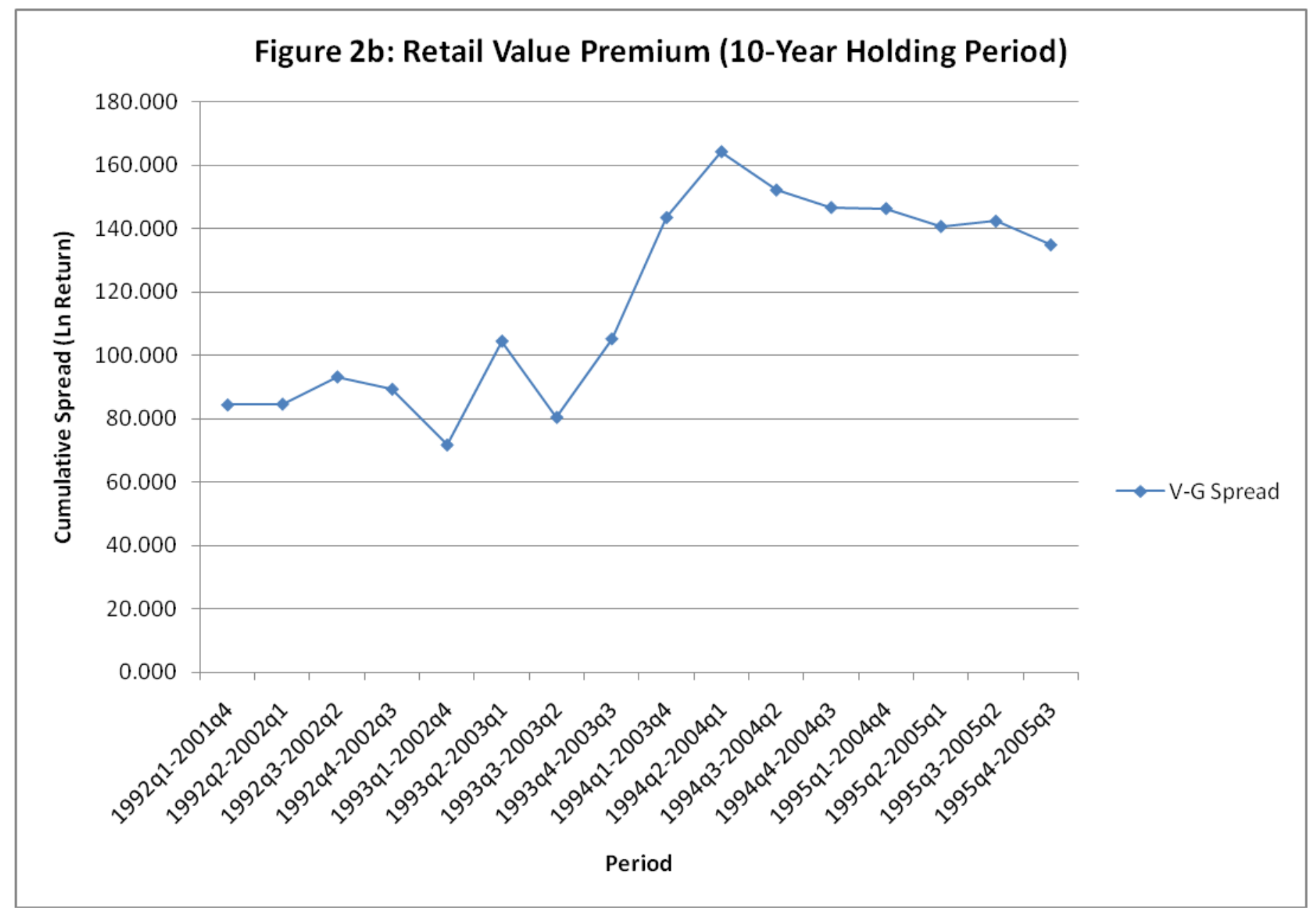




\section{Table 1: Descriptive Ln Return Statistics}

We report descriptive statistics for the value and growth portfolios for the office and retail sectors over their respective different holding periods. The statistics are: the mean ln return (column 3), standard deviation (column 4) and coefficient of variation (column 5).

\begin{tabular}{|c|c|c|c|c|c|c|c|}
\hline \multicolumn{8}{|c|}{ Table 1: Descriptive Ln Return Statistics } \\
\hline \multirow{2}{*}{ Sectors } & \multirow{2}{*}{ Holding Period } & \multicolumn{2}{|c|}{ Mean Return (\%) } & \multicolumn{2}{|c|}{ Standard Deviation } & \multicolumn{2}{|c|}{ Coefficient of Variation } \\
\hline & & Value & Growth & Value & Growth & Value & Growth \\
\hline \multirow[t]{4}{*}{ Office } & 5 Years & 60.38 & 21.48 & 42.83 & 42.73 & 0.71 & 1.99 \\
\hline & 10 Years & 119.29 & 42.85 & 53.77 & 43.11 & 0.45 & 1.01 \\
\hline & 15 Years & 225.27 & 66.54 & 45.84 & 17.28 & 0.20 & 0.26 \\
\hline & $>15$ Years & 278.78 & 79.62 & 73.08 & 19.22 & 0.26 & 0.24 \\
\hline \multirow{3}{*}{ Retail } & 5 Years & 103.41 & 45.38 & & 18.04 & & \\
\hline & 10 Years & 197.20 & 79.47 & 47.16 & 15.55 & 0.24 & 0.20 \\
\hline & $>10$ Years & 237.62 & 110.90 & 24.38 & 6.68 & 10.26 & 6.02 \\
\hline
\end{tabular}


Table 2: Equality of Means/Variance Test

We report test statistics for the equality of means return including value-growth spread (Table 2a) and their corresponding variance tests for value \& growth portfolios.

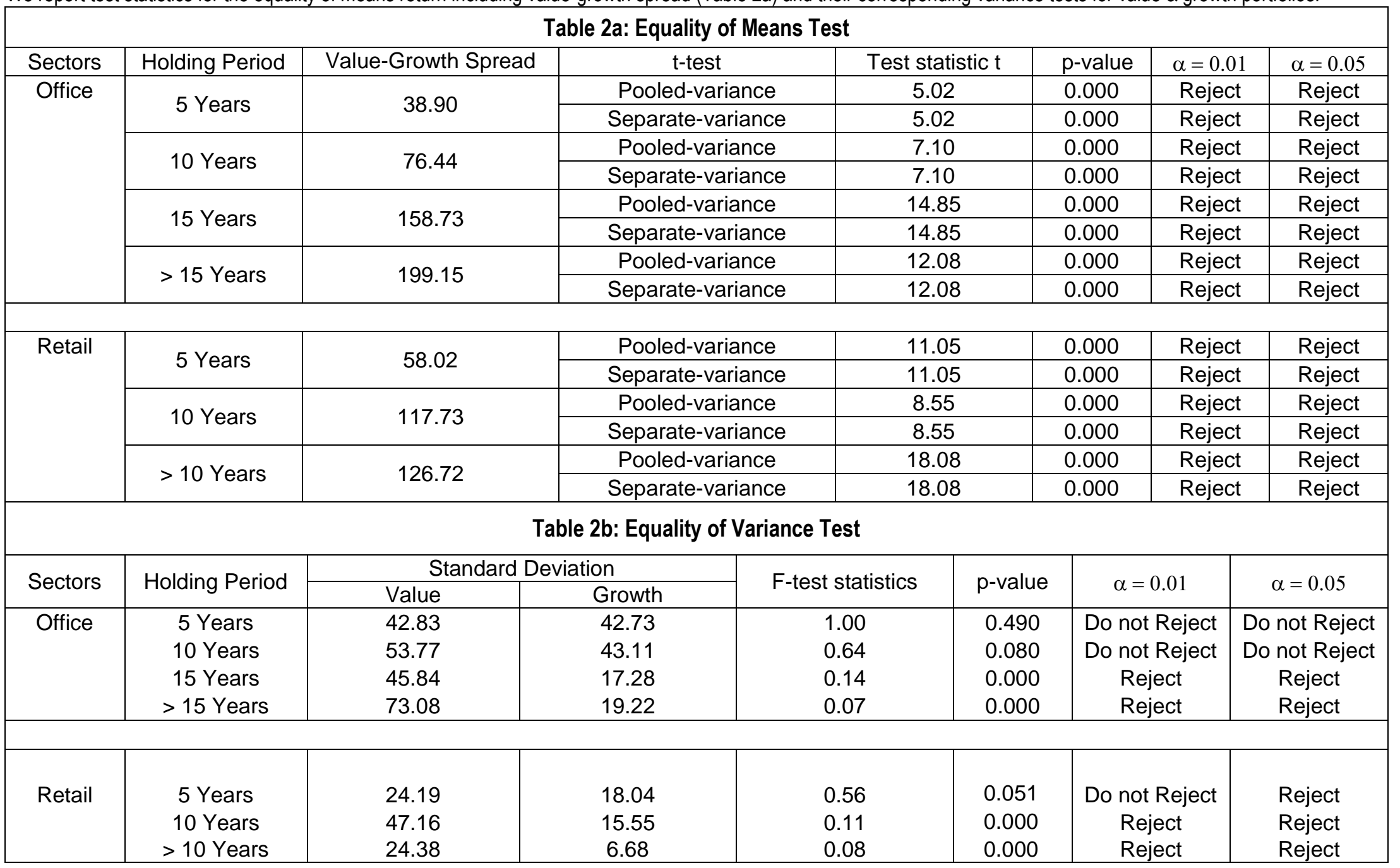


Table 3a: Office Beta-Premium Regression Results (5-Year Holding Period)

The mean conditional rolling and fitted betas in the four economic states: Trough, Recession, Expansion and Peak for the Office Value minus Growth portfolios over the 5-Year holding period are presented in this Table. We use 20 rolling-window regressions to estimate the rolling betas while the fitted betas are estimated via conditional market regressions using four conditioning variables: rental yields, value-growth spread, term spread (difference between US government 10- and 1-year bond rates), and one-month US government Treasury Bill rate, and a constant. We also report Value and Growth beta-premium sensitivities, $\varphi$, with their standard errors for "Trough" and "Peak", and for the entire period (i.e. all 4 economic states) as well as the Value minus Growth beta -premium sensitivity for the entire period. The standard errors are adjusted for heteroskedasticity and autocorrelation for up to 20 quarters.

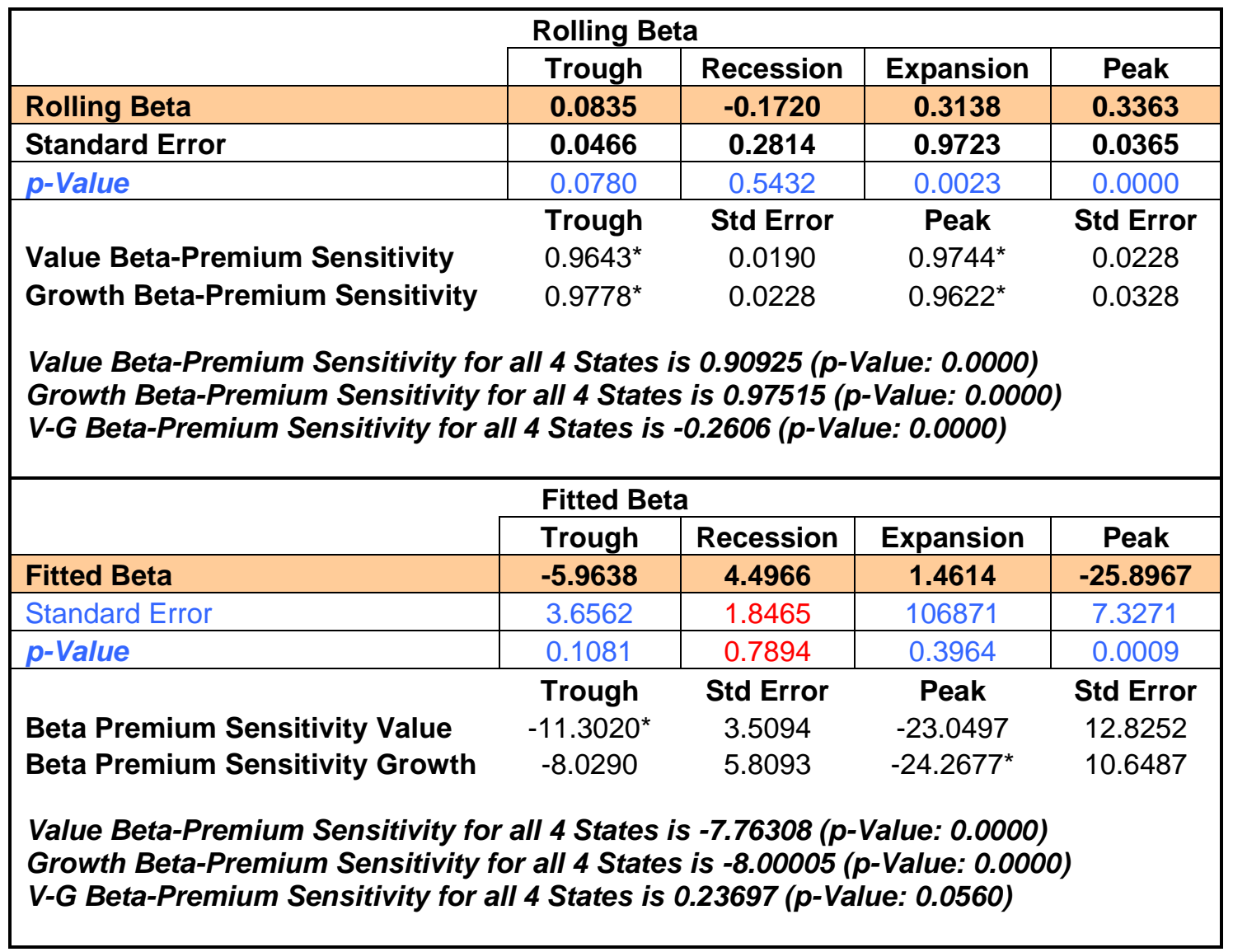

Note:

For Value beta-premium sensitivity, $\mathrm{H}_{0}: \varphi>0$

For Growth beta-premium sensitivity, $\mathrm{H}_{0}: \varphi<0$

*Denotes statistical significance at both 0.01 and 0.05 levels. 


\section{Table 3b: Office Beta-Premium Regression Results (10-Year Holding Period)}

We report the mean conditional rolling and fitted betas in the four economic states: Trough, Recession, Expansion and Peak for the Office Value minus Growth portfolios over the 10-Year holding period in this Table. We use 40 rollingwindow regressions to estimate the rolling betas while the fitted betas are estimated via conditional market regressions using four conditioning variables: rental yields, value-growth spread, term spread (difference between US government 10- and 1-year bond rates), and one-month US government Treasury Bill rate, and a constant. We also report Value and Growth beta-premium sensitivities, $\varphi$, with their standard errors for "Trough" and "Peak", and for the entire period (i.e. all 4 economic states) as well as the Value minus Growth beta-premium sensitivity for the entire period. The standard errors are adjusted for heteroskedasticity and autocorrelation for up to 40 quarters.

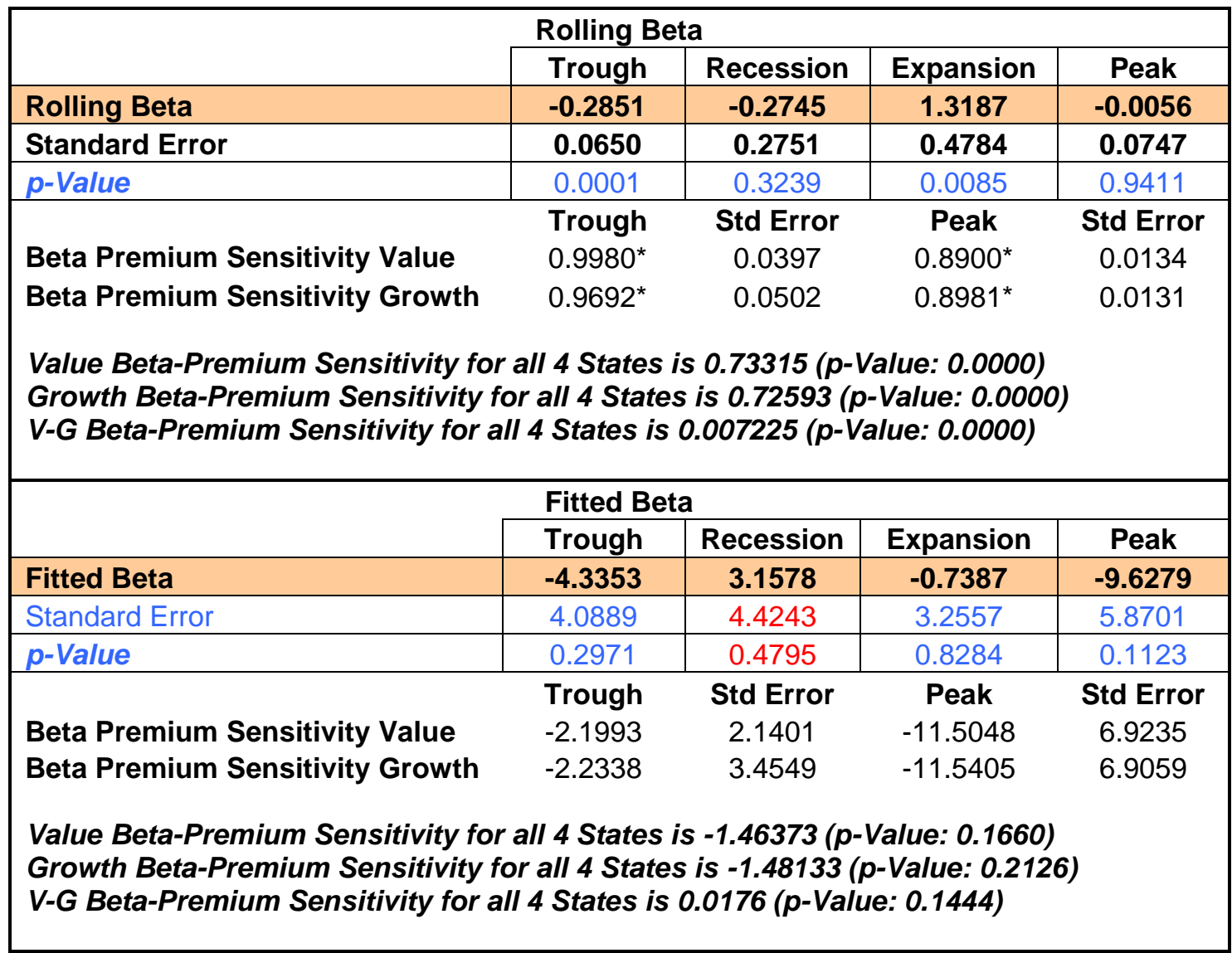

Note:

For Value beta-premium sensitivity, $\mathrm{H}_{\mathrm{o}}: \varphi>0$

For Growth beta-premium sensitivity, $\mathrm{H}_{0}: \varphi<0$

*Denotes statistical significance at both 0.01 and 0.05 levels. 


\section{Table 3c: Office Beta-Premium Regression Results (15-Year Holding Period)}

The mean conditional rolling and fitted betas in the four economic states: Trough, Recession, Expansion and Peak for the Office Value minus Growth portfolios over the 15-Year holding period are presented in this Table. We use 60 rolling-window regressions to estimate the rolling betas while the fitted betas are estimated via conditional market regressions using four conditioning variables: rental yields, value-growth spread, term spread (difference between US government 10- and 1-year bond rates), and one-month US government Treasury Bill rate, and a constant. We also report Value and Growth beta-premium sensitivities, $\varphi$, with their standard errors for "Trough" and "Peak", and for the entire period (i.e. all 4 economic states) as well as the Value minus Growth beta-premium sensitivity for the entire period. The standard errors are adjusted for heteroskedasticity and autocorrelation for up to 60 quarters.

\begin{tabular}{|c|c|c|c|c|}
\hline \multicolumn{5}{|c|}{ Rolling Beta } \\
\hline & Trough & Recession & Expansion & Peak \\
\hline Rolling Beta & 0.1904 & -0.7015 & -0.9467 & -0.1493 \\
\hline Standard Error & 0.2684 & 0.8209 & 0.4054 & 0.0264 \\
\hline$p$-Value & 0.4883 & 0.5432 & 0.0000 & 0.0000 \\
\hline Beta Premium Sensitivity Value & $\begin{array}{l}\text { Trough } \\
0.855^{\star}\end{array}$ & $\begin{array}{c}\text { Std Error } \\
0.0265\end{array}$ & $\begin{array}{c}\text { Peak } \\
0.6177^{*}\end{array}$ & $\begin{array}{c}\text { Std Error } \\
0.0065\end{array}$ \\
\hline \multicolumn{5}{|c|}{$\begin{array}{l}\text { Value Beta-Premium Sensitivity for all } 4 \text { States is } 0.569775 \text { ( } p \text {-Value: } 0.0000) \\
\text { Growth Beta-Premium Sensitivity for all } 4 \text { States is } 0.56905 \text { (p-Value: } 0.0000) \\
\text { V-G Beta-Premium Sensitivity for all } 4 \text { States is } 0.000725 \text { (p-Value: } 0.0000)\end{array}$} \\
\hline \multicolumn{5}{|c|}{ Fitted Beta } \\
\hline & Trough & Recession & Expansion & Peak \\
\hline Fitted Beta & -2.0934 & -12.4878 & -12.8989 & -0.4347 \\
\hline Standard Error & 5.8189 & 4.2216 & 5.4093 & 1.0892 \\
\hline$p$-Value & 0.7236 & 0.0075 & 0.0271 & 0.3833 \\
\hline $\begin{array}{l}\text { Beta Premium Sensitivity Value } \\
\text { Beta Premium Sensitivity Growth } \\
\text { Value Beta-Premium Sensitivity fo } \\
\text { Growth Beta-Premium Sensitivity } \\
\text { V-G Beta-Premium Sensitivity for }\end{array}$ & $\begin{array}{l}\text { Trough } \\
-1.6847 \\
-15.2386\end{array}$ & $\begin{array}{c}\text { Std Error } \\
2.2445 \\
7.8158 \\
\\
-9.86725(p \\
\text { is }-13.3647 \\
.49745(p-V\end{array}$ & $\begin{array}{c}\text { Peak } \\
-1.7016 \\
-3.1895 \\
\\
\text { /alue: } 0.2272 \\
\text {-Value: } 0.087 \\
\text { ue: } 0.0141)\end{array}$ & $\begin{array}{l}\text { Std Error } \\
2.1030 \\
2.6014\end{array}$ \\
\hline
\end{tabular}

Note:

For Value beta-premium sensitivity, $\mathrm{H}_{\mathrm{o}}: \varphi>0$

For Growth beta-premium sensitivity, $\mathrm{H}_{0}: \varphi<0$

*Denotes statistical significance at both 0.01 and 0.05 levels. 


\section{Table 4a: Retail Beta-Premium Regression Results (5-Year Holding Period)}

The mean conditional rolling and fitted betas in the four economic states: Trough, Recession, Expansion and Peak for the Retail Value minus Growth portfolios over the 5-Year holding period are presented in this Table. We use 20 rolling-window regressions to estimate the rolling betas while the fitted betas are estimated via conditional market regressions using four conditioning variables: rental yields, value-growth spread, term spread (difference between US government 10- and 1-year bond rates), and one-month US government Treasury Bill rate, and a constant. We also report Value and Growth beta-premium sensitivities, $\varphi$, with their standard errors for "Trough" and "Peak", and for the entire period (i.e. all 4 economic states) as well as the Value minus Growth beta-premium sensitivity for the entire period. The standard errors are adjusted for heteroskedasticity and autocorrelation for up to 20 quarters.

\begin{tabular}{|c|c|c|c|c|}
\hline \multicolumn{5}{|c|}{ Rolling Beta } \\
\hline & Trough & Recession & Expansion & Peak \\
\hline Rolling Beta & 0.0364 & 0.0616 & 0.2516 & -0.0345 \\
\hline Standard Error & 0.0338 & 0.0638 & 0.0979 & 0.0298 \\
\hline$p$-Value & 0.2894 & 0.3414 & 0.0166 & 0.2561 \\
\hline Durbin-Watson stat & 0.8630 & 1.3551 & 1.7617 & 1.9706 \\
\hline \multicolumn{2}{|r|}{ Trough } & Std Error & Peak & Std Error \\
\hline \multirow{2}{*}{$\begin{array}{l}\text { Value Beta Premium Sensitivity } \\
\text { Growth Beta Premium Sensitivity }\end{array}$} & $0.9538^{*}$ & 0.0190 & $0.9075^{*}$ & 0.0105 \\
\hline & $0.9427^{*}$ & 0.0187 & $0.9090^{*}$ & 0.0100 \\
\hline \multicolumn{5}{|c|}{$\begin{array}{l}\text { Value Beta-Premium Sensitivity for all } 4 \text { States is } 0.46955 \text { ( } p \text {-Value: } 0.0000) \\
\text { Growth Beta-Premium Sensitivity for all } 4 \text { States is } 0.46780 \text { ( } p \text {-Value: } 0.0000) \\
\text { V-G Beta-Premium Sensitivity for all } 4 \text { States is } 0.00175 \text { ( } p \text {-Value: } 0.0000)\end{array}$} \\
\hline \multicolumn{5}{|c|}{ Fitted Beta } \\
\hline & Trough & Recession & Expansion & Peak \\
\hline Fitted Beta & -4.9406 & -4.5225 & -1.0163 & -10.8569 \\
\hline Standard Error & 12.7883 & 5.2007 & 4.4388 & 6.3864 \\
\hline \multirow[t]{2}{*}{$p$-Value } & 0.7018 & 0.3907 & 0.8170 & 0.1007 \\
\hline & Trough & Std Error & Peak & Std Error \\
\hline Beta Premium Sensitivity Value & -0.0865 & 4.1348 & -15.8774 & 10.0766 \\
\hline Beta Premium Sensitivity Growth & 4.9550 & 9.2849 & -73.8925 & 35.9476 \\
\hline \multicolumn{5}{|c|}{$\begin{array}{l}\text { Value Beta-Premium Sensitivity for all } 4 \text { States is }-3.16615 \text { (p-Value: } 0.45148) \\
\text { Growth Beta-Premium Sensitivity for all } 4 \text { States is }-17.1603 \text { (p-Value: } 0.5034 \text { ) } \\
\text { V-G Beta-Premium Sensitivity for all } 4 \text { States is } 13.99415 \text { ( } p \text {-Value: } 0.2364)\end{array}$} \\
\hline
\end{tabular}

Note:

For Value beta-premium sensitivity, $\mathrm{H}_{\mathrm{o}}: \varphi>0$

For Growth beta-premium sensitivity, $\mathrm{H}_{\mathrm{o}}: \varphi<0$

*Denotes statistical significance at both 0.01 and 0.05 levels. 


\section{Table 4b: Retail Beta-Premium Regression Results (10-Year Holding Period)}

The mean conditional rolling and fitted betas in the four economic states: Trough, Recession, Expansion and Peak for the Retail Value minus Growth portfolios over the 10-Year holding period are presented in this Table. We use 40 rolling-window regressions to estimate the rolling betas while the fitted betas are estimated via conditional market regressions using four conditioning variables: rental yields, value-growth spread, term spread (difference between US government 10- and 1-year bond rates), and one-month US government Treasury Bill rate, and a constant. We also report Value and Growth beta-premium sensitivities, $\varphi$, with their standard errors for "Trough" and "Peak", and for the entire period (i.e. all 4 economic states) as well as the Value minus Growth beta-premium sensitivity for the entire period. The standard errors are adjusted for heteroskedasticity and autocorrelation for up to 40 quarters.

\begin{tabular}{|c|c|c|c|c|}
\hline \multicolumn{5}{|c|}{ Rolling Beta } \\
\hline & Trough & Recession & Expansion & Peak \\
\hline Rolling Beta & -0.0227 & 0.1198 & -0.0004 & 0.0415 \\
\hline Standard Error & 0.0729 & 0.1021 & 0.0071 & 0.0587 \\
\hline$p$-Value & 0.7591 & 0.2589 & 0.9598 & 0.5054 \\
\hline $\begin{array}{l}\text { Beta Premium Sensitivity Value } \\
\text { Beta Premium Sensitivity Growth } \\
\text { Value Beta-Premium Sensitivity fo } \\
\text { Growth Beta-Premium Sensitivity } \\
\text { V-G Beta-Premium Sensitivity for }\end{array}$ & \multicolumn{4}{|c|}{$\begin{array}{l}\text { Value Beta-Premium Sensitivity for all } 4 \text { States is } 0.52266 \text { (p-Value: } 0.0000) \\
\text { Growth Beta-Premium Sensitivity for all } 4 \text { States is } 0.518064 \text { ( } p \text {-Value: } 0.0000) \\
\text { V-G Beta-Premium Sensitivity for all } 4 \text { States is } 0.0046 \text { (p-Value: } 0.0000)\end{array}$} \\
\hline \multicolumn{5}{|c|}{ Fitted Beta } \\
\hline & Trough & Recession & Expansion & Peak \\
\hline Fitted Beta & -16.8587 & -10.9687 & 45.5541 & 94.3666 \\
\hline Standard Error & 4.5652 & 2.3811 & 10.3563 & 38.2366 \\
\hline$p$-Value & 0.0027 & 0.0006 & 0.00048 & 0.0902 \\
\hline $\begin{array}{l}\text { Beta Premium Sensitivity Value } \\
\text { Beta Premium Sensitivity Growth } \\
\text { Value Beta-Premium Sensitivity fo } \\
\text { Growth Beta-Premium Sensitivity } \\
\text { V-G Beta-Premium Sensitivity for }\end{array}$ & $\begin{array}{l}\text { Trough } \\
-13.0144^{*} \\
15.1609\end{array}$ & $\begin{array}{l}\text { Std Error } \\
4.1934 \\
51.3596\end{array}$ & $\begin{array}{l}\text { Peak } \\
67.3900^{\star *} \\
63.2564 \\
\text { alue: } 0.0158 \\
\text {-Value: } \mathbf{0 . 2 0} \\
\text { 699) }\end{array}$ & $\begin{array}{l}\text { Std Error } \\
25.9874 \\
26.0712\end{array}$ \\
\hline
\end{tabular}

Note:

For Value beta-premium sensitivity, $\mathrm{H}_{\mathrm{o}}: \varphi>0$

For Growth beta-premium sensitivity, $\mathrm{H}_{\mathrm{o}}: \varphi<0$

*Denotes statistical significance at both 0.01 and 0.05 levels.

** Denotes statistical significance at the 0.05 level. 
Table 5: Jensen's Alpha from Conditional Market Regressions

We present in this table the Jensen's alpha $(\alpha)$ and standard error (se) from the conditional market regressions using four conditioning variables: rental yields, value-growth spread, term spread (difference between US government 10- and 1-year bond rates), and one-month US government Treasury Bill rate, and a constant which is the alpha. The standard errors are adjusted for heteroskedasticity and autocorrelation of up to 20,40 and 60 quarters respectively to the holding periods.

\begin{tabular}{|c|c|c|c|c|}
\hline \multirow{2}{*}{$\begin{array}{c}\text { Holding Period } \\
\text { in Years }\end{array}$} & $\alpha$ & Se & $\alpha$ & se \\
\cline { 2 - 5 } & 2.0081 & 0.0865 & 2.7721 & 0.1551 \\
\hline 5 & 2.3348 & 0.0476 & 6.226 .1 & 3.0421 \\
\hline 10 & 2.1309 & 0.0576 & & \multicolumn{2}{|c|}{ NA } \\
\hline 15 & & & & \\
\hline
\end{tabular}


Table 6: Initial Yield, Past \& Future Performances of Value \& Growth Property Portfolio The Table evaluates the overreaction/naïve extrapolation hypothesis to ascertain their credibility in explaining the superiority of the value portfolio. This is achieved through a comparison of the past and future (i.e. before and postportfolio formation) performances of value and growth portfolios vis-à-vis the respective initial yield at the end of the quarter preceding portfolio formation. The value and growth portfolios were formed in 1994Q3 (Office) and 1998Q1 (Retail) which divide the periods under investigation into two equal halves. Panel A exhibits the initial yields while Panels B and C provide the past and future performances.

\begin{tabular}{|c|c|c|c|c|c|}
\hline Panel A (C & Retail Portfolios f & beginnir & $994 Q 38$ & Q1 respe & \\
\hline Type & Time & & & & \\
\hline & & & & & \\
\hline Office & 1994Q2 & & & & \\
\hline Retail & 1997Q4 & & & & \\
\hline Panel B: P & rmance (Before $P$ & ormatic & & & \\
\hline & & Capital & Rental & Capital & Rental \\
\hline Office & 1985Q1-1994Q2 & 6.99 & -0.56 & -2.4 & 14.36 \\
\hline Retail & 1992Q1-1997Q4 & 0.21 & -1.87 & 2.60 & 17.40 \\
\hline Panel C: F & rformance (Post-I & Formati & & & \\
\hline Office & 1994Q4-2004Q2 & -2.41 & -0.51 & 1.21 & 5.96 \\
\hline Retail & 1998Q2-2004Q2 & 0.71 & 0.01 & 2.27 & 3.65 \\
\hline
\end{tabular}

